\title{
Synergia epistemologiczna na przykładzie wybranych zagadnień semiotyki znaku językowego w retrospektywie
}

\author{
Malgorzata Haladewicz-Grzelak \\ Politechnika Opolska \\ m.haladewicz-grzelak@po.edu.pl
}

Streszczenie

Przedmiotem artykutu jest studium synergii epistemologicznej $w$ domenie semiotyki znaku językowego na przykładzie niektórych aspektów semiotycznego wymiaru dzieła językoznawców, często przesłanianego przez ich bardziej spektakularne teorie językoznawstwa formalnego. Badanie wpisuje sie $w$ kanon semiotyki jezzkoznawczej, rozwijany od wielu lat $w$ pracach Zdzisława Wasika (np. 1996, 2017). Do bazy analitycznej wybrałam omówienia dwojakiego rodzaju: zarówno przykłady dziet językoznawców mniej popularnych wśród polskojęzycznej akademii (na przykład Yishai Tobin, Julia Kristeva), jak i przykłady myśli naukowców bardzo znanych, ale rozważanych z nietypowej perspektywy ich mniej cytowanych dziet (Ferdynand de Saussure (1878-79), Charles Morris czy Roman Jakobson (1973). Główna tezę artykutu synergie epistemologiczna - rozumiem jako uwypuklenie sposobu, w jaki badania prowadzone w jednej dziedzinie wspierały rozwój pokrewnych paradygmatów.

Słowa kluczowe: synergia, semiotyka, znak językowy, epistemologia, historiografia.

Abstract

Synergic Semiotics of a Linguistic Sign: a Retrospective of Selected Accomplishments

The subject of the article is a study of epistemological synergy in the realm of the semiotics of a linguistic sign as exemplified by selected aspects of semiotic dimension of the work of linguists, which tends to be foreshadowed by their more spectacular achievements in formal linguistics. The study fits in the canon of linguistic semiotics, developed for many years in the research of Zdzistaw Wasik (e.g. 1996, 2017). The paper contains two types of research avenues: on the one hand, the study of some aspects of the work of linguists who are less popular among Polishlanguage scholars (for example, Yishai Tobin, Julia Kristeva) and, on the other, thoughts of well-known scholars, but considered here from an unusual perspective of their less cited works (Ferdinand de Saussure (1878-79) or Roman Jakobson (1973)). Epistemological synergy, the analytical pivot for the presented discussion is understood as the way in which research conducted in one field can foster the development of related paradigms.

Key words: synergy, semiotics, linguistic sign, epistemology, historiography. 


\section{Wprowadzenie}

Przy określaniu związku metod badawczych językoznawstwa i semiotyki należy zwrócić uwagę na bardzo ważne rozróżnienie, a mianowicie podział polegający na kierunkowości przenikania się językoznawczych i semiotycznych perspektyw, co jak podkreślił Zdzisław Wąsik (2014: 47 i nast. zob. też np. Chrzanowska-Kluczewska 2015; Marty 1990), przekłada się na restryktywne lub szerokie spojrzenie na semiotykę jako taką. W niniejszym artykule rozważam zagadnienie synergii epistemologicznej na przykładzie retrospektywy teoretyzowania semiotyki znaku językowego. Bazę do dyskusji stanowią niektóre aspekty myśli naukowej wybranych językoznawców, którzy bardziej są znani z dokonań spoza dziedziny semiotyki / semiologii ${ }^{1}$.

Wybór, którego dokonałam miał na względzie przede wszystkim opisanie jak najszerszego kręgu zróżnicowania epistemologicznego, jednocześnie biorąc pod uwagę ograniczenia związane z formą (długością) artykułu naukowego. Dokonania językoznawcze praktycznie wszystkich myślicieli wspomnianych w artykule (Romana Osipowicza Jakobsona, Wolfganga U. Dresslera i Ferdynanda de Saussure'a w szczególności) doczekały się ogromnej liczby opracowań i analiz naukoznawczych, jak również polemik. Dlatego każda próba retrospektywnego i całościowego uchwycenia jakiegokolwiek wycinka ich dorobku jest zadaniem co najmniej złożonym i ryzykownym, co zresztą znacznie przekraczałoby zakres tematyczny niniejszego studium. Pisząc o sposobach pojmowania semiotyki przez wybranych językoznawców, chciałabym się zatem skupić głównie na pewnych ogólnych punktach odniesienia, które przybliżyłyby czytelnikowi językoznawczy praxis semiotyki, jak również rzucić historiograficzne światło na mniej znane aspekty więzi między tymi dwiema dziedzinami ${ }^{2}$.

Inherentność subiektywizmu $\mathrm{w}$ doborze materiału badanego podkreśliła Katarzyna Dziubalska-Kołaczyk (2001-2002: 15), zauważając, iż 'każdy wyrażony pogląd, pod którym autor podpisany jest z imienia i nazwiska, należy traktować jako osobisty [wyróżnienie moje, M.H.-G.]'. W tym zakresie, zaproponowane studium poniekąd będzie współgrało $\mathrm{z}$

\footnotetext{
${ }^{1}$ Wszystkie tłumaczenia zawarte $w$ artykule są mojego autorstwa, M.H.-G. Jeśli nie są one wyjęte z tekstu głównego jako rozszerzony cytat, pojawiają się w pojedynczym cudzysłowie. Szersze opracowanie zagadnienia wzajemnych wpływów dziedzin takich jak antropologia, fonologia i semiotyka (szczególnie w odniesieniu do myśli Mikołaja Trubieckiego, Romana Jakobsona i Claude'a Lévi-Straussa) zawarłam w pracy Haładewicz-Grzelak (2018). Chciałabym podziękować anonimowym recenzentom PJT za ich czas i wnikliwe uwagi, które znacznie przyczyniły się do poprawy ostatecznej wersji niniejszego tekstu.

${ }^{2}$ Empiryczne zastosowanie synergicznego wymiaru tu omawianego w perspektywie teoretycznej zawarłam w moim długoletnim projekcie badawczym jako postulowaną semiotaktykę - metodologię polegającą na zastosowaniu osiągnięć fonologii współczesnej do analiz tekstów wizualnych (patrz np. Haładewicz-Grzelak 2012, 2018, [w druku]).
} 
opracowaniem zaproponowanym w cytowanej powyżej pracy Dziubalskiej-Kołaczyk, gdzie badaczka proponuje między innymi retrospektywny przegląd teorii językoznawczych pod kątem użycia zasady „,naturalności”, jako 'zdeklarowanego uczestnika' ('a convinced insider') językoznawstwa naturalnego (Dziubalska-Kołaczyk 2001-2002: 1). Jak zauważa ta językoznawczyni, celem jej opracowania było zainicjowanie dyskusji i wezwanie do zgłaszania komentarzy, co na dłuższą metę przyczyniłoby się do wzmocnienia pozycji językoznawstwa naturalnego wobec innych współczesnych teorii językoznawczych (Dziubalska-Kołaczyk 2001-2002: 1). Podobny zamysł zakłada też i obecny artykuł: z jednej strony, skłonienie do refleksji nad związkami semiotyki z językoznawstwem, zwrócenie uwagi na semiotyczny wymiar dociekań językoznawczych, a z drugiej, przedstawienie ważniejszych kierunków badań znakowości zarówno we współczesności, jak i w przeszłości.

Chciałabym też tytułem wstępu wspomnieć inną inspirującą retrospektywę prądów językoznawczych, przeprowadzoną pod kątem aksjomatyzacji i przedłożoną w pracy Jerzego Bańczerowskiego (2004), którą badacz wprowadza w następujących słowach: „autor jest w pełni świadom tego, że to, kim jest, zawdzięcza również swoim poprzednikom i współczesnym, z których dziełami mógł się zapoznać i które go kształtowały poprzez to, że je akceptował lub odrzucał” (Bańczerowski 2004: 16). Dalej językoznawca ten zauważa, że oprócz dominujących nurtów, w lingwistyce kształtuje się bez rozgłosu alternatywny nurt, patrzący na zjawiska i teorie językowe pod zupełnie innym kątem, a owa „świeżość inności może okazać się co najmniej inspirująca” (Bańczerowski 2004: 16). Niniejszy artykuł wpisuje się właśnie w teoretyczną linię badawczą reprezentowaną m. in przez te powyżej wspomniane prace.

Epistemologiczne podstawy językoznawstwa jako nauki o znakach, jak również wielobiegunowość znaku, kontrowersje wokół epistemologicznych podstaw semiotyki, konsekwencje pojmowania granic przedmiotów semiotycznych, klasyfikacje perspektyw badawczych, czy ukonstytuowanie semiotyki lingwistycznej wraz z bogatym wyborem źródeł zostały opracowane w serii wieloletnich prac Zdzisława Wąsika (szczególnie patrz: Wąsik 1997, 2014, 2017) ${ }^{3}$. Myśliciel ten określa epistemologię jako 'teorię wiedzy odnośnie do sposobu, w

\footnotetext{
${ }^{3}$ Te aspekty analizy semiotycznej nie będą tu omawiane. Nie pojawi się również dyskusja nad semiotycznymi i dyskursywnymi aspektami znaczenia. Zwięzłe omówienie niektórych konceptualizacji 'znaczenia' czytelnik może znaleźć np. w pracy Grzegorczykowa (1990) czy Wąsik (1997). Ten ostatni szczególnie zwraca uwagę na relacje znaczeniowe w semiotyce, podkreślając, że „zróżnicowanie rozumienia terminu znaczenie nie odpowiada na zasadzie jeden do jednego [bi-unikalnie] różnym sformułowaniom notacyjnego kształtu znaku, jako podstawowej kategorii semiotycznej” (Wąsik 1997: 55). Kontrowersje oscylują na przykład wokół następujących zagadnień: „,czy znaczenie jest procesem, czy produktem, czy jest abstrakcyjne czy konkretne, konkludowane czy intencjonalne, czy rezyduje po stronie znaku czy po stronie jego desygnatu, czy można je wykryć z ekstrospektywnych czy introspektywnych obserwacji efektu, jaki znak powoduje na uczuciach, z reakcji czy zachowania użytkowników znaku, czy znaczenie można wyprowadzać z inter-relacji między znakami czy / i / lub między znakami a
} 
órfzy jaki naukowe obiekty istnieją (ontologia) i jak mogą być pojmowane w podejściach badawczych (gnoseologia)' (Wąsik 2014: 17) . W świetle powyższego, paradygmat semiotyki językoznawczej zbudowany jest z połączenia językoznawczych, antropologicznych, logicznych i filozoficznych wglądów w pytania związane ze znaczeniem i znakiem (Wąsik 2014: 17)5.

Na synergię epistemologiczną nauk wizualnych i językoznawstwa można patrzeć również w dużo szerszej perspektywie. Na przykład, badania połączeń między figuracją wizualną a tropologicznym wymiarem tekstu stanowią wieloletni projekt badawczy Elżbiety Chrzanowskiej-Kluczewskiej, szczególnie w odniesieniu do procedur interpretacyjnych odbiorcy (patrz np. Chrzanowska-Kluczewska 2013, 2015, 2017 inter alia). Badaczka podkreśla, iż ,[z]e wszystkimi, którzy skłonni są uznać figurację jako zjawisko intersemiotyczne, pragnę dzielić przekonanie o istnieniu wspólnej stylistycznej struktury, odpowiedzialnej za konstrukcję spójnego tekstu semiotycznego" (Chrzanowska-Kluczewska 2015: 126) ${ }^{6}$. W niniejszej retrospektywie takie szerokie ujęcie nie będzie uwzględnione - skupię się przede wszystkim na wybranych aspektach teoretyzowania zależności między działaniami mownymi a semiotyką w obszarze immanentnej systemowej znakowości języka, na podstawie niektórych wątków w działach Mikołaja Kruszewskiego, Ferdynanda de Saussure'a, Charlesa Morrisa, Louisa Trolle Hjelmsleva, Romana Jakobsona, Julii Kristevy i Yishaia Tobina. Korzystam zarówno z oryginalnych tekstów omawianych myślicieli, jak i w niektórych wypadkach, z opublikowanych prac historiograficznych (Joanna Radwańska-Willams, E.F.K. Koerner, Sungdo Kim czy Piotr Stalmaszczyk inter alia.).

Główny paradygmat tekstu, synergię epistemologiczną, rozumiem zgodnie z wymiarem badawczym proponowanym w pracach na przykład Stanisława Puppela, jako współgranie kilku czynników, dające w rezultacie pewną wartość dodaną, jakość większą niż pojedyncze czynniki wzięte razem. Badacz ten odnosi synergię głównie do wymiaru ekolingwistyki (2009) jak i całościowo rozpatrywanego aktu komunikatywnego (2017). W niniejszym artykule synergia

kontekstami ich użycia i / czy spośród użytkowników tych znaków (...). W konfrontacji z tymi i innymi odpowiednimi propozycjami celu ogólnej teorii znaków i/lub procesów znakowości, semiotyk musi zadecydować, czy wyprowadzić znaczenie z relacji (1) między wyrażeniem signifier i zawartości signified (2) pomiędzy wyrażeniem signifier i funkcji signified czy (3) pomiędzy wyrażeniem signifier i wartością oznaczaną (signifed value) przedmiotów pojmowanych jako semiotyczne" (Wąsik 1998: 56-60).

${ }^{4}$ Zob. również Wąsik (1997: 7), (2017, Rozdział I).

5 Należy tu też wspomnieć wyczerpujące opracowanie historiograficzno-teoretyczne Piotra Chruszczewskiego (2011) czy też panchroniczne badania Heleny Pociechiny (2009).

${ }^{6}$ Stając po stronie historyków sztuki i semiotyków takich jak np. Ernst H. Gombrich, Roland Barthes czy Seweryna Wysołuch, krakowska badaczka podkreśla, i udowadnia, że w pełni zasadne jest mówienie o tropach takich jak metonimia, metafora, synekdocha czy ironia w sztukach wizualnych (Chrzanowska-Kluczewska 2012: 72). 
epistemologiczna oznacza możliwość pełniejszego oglądu badawczego w przypadku wsparcia dokonań semiotyki (semiologii) i językoznawstwa niż byłoby to możliwe przy rozwijaniu każdej z dziedzin w izolacji.

W pogoni za „nowymi” rozwiązaniami w teorii językoznawstwa czasami zdarza się nam zapomnieć, jak piękny i inspirujący dorobek dostaliśmy w spadku, zapisany w ciągu dekad badań prowadzonych przez pokolenia wybitnych językoznawców, którzy nas poprzedzali. Karl Bühler, naukowy przykład synergii par excellence, którego wkład ze względu na ograniczenia ilościowe tekstu nie mógł być tu omówiony, we wprowadzeniu do swojego dzieła Teoria języka ujął to zagadnienie następująco:

Chciałbym podkreślić, że wszystkie kluczowe prawdy, jakie przyjdzie nam tu przedstawić, odnajdziemy w dziełach wybitnych językoznawców przeszłości, począwszy od płaszczyzny deiktycznej (Zeigfeld) znanej już starożytnych Grekom, a odkrytej na nowo przez takich nowszych badaczy jak Wagner, Brugmann, Gardnier, aż po subtelne rozważania dotyczące płaszczyzny symbolicznej (Symbolfeld) która stała zawsze w centrum analizy gramatycznej (...). O niniejszym dziele bardziej niż o jakiejkolwiek innej książce powiedzieć można słowami Goethowskiego Tussa ,żem to od was posiadł”.

(Bühler 1934/1999 [2004]: XVI)

Podsumowując wprowadzenie do perspektywy i zakresu badawczego tego tekstu, należy zrobić kilka zastrzeżeń. Zgodnie z wprowadzającym motto Katarzyny DziubalskiejKołaczyk, przedstawione opracowanie i dobór omawianych prac ilustrujących zagadnienie synergii epistemologicznej są rzeczywiście osobiste, jako stanowisko epistemologiczne 'zdeklarowanego uczestnika'. Z drugiej strony, niniejszy artykuł należy rozpatrywać jako kolejną część mojego wieloletniego projektu historiograficznego, w którym podejmuję badania, które można by nazwać ‘hermeneutycznym spojrzeniem na językoznawstwo' czy też jego hermeneutyczną historiografią. W ramach tego projektu, kilka prac poświęciłam już mistrzowi z Genewy, młodogramatykom, André Martinetowi, Ludwikowi Zabrockiemu czy Noamowi Chomskiemu (np. Haładewicz-Grzelak [2014, 2015, 2017] inter alia). Ze względu na ograniczenia formy artykułu naukowego, nie ma możliwości zawarcia w jednym raporcie akademickim całościowego opracowania, zresztą w nauce pojęcia typu „całościowe opracowanie" powinny być zawsze traktowane z ostrożnością ${ }^{7}$. Dlatego też, dokonując

\footnotetext{
7 Przykładem w miarę całościowego opracowania może być książka Kristevy (1989), aczkolwiek i tam pojawiają się tylko wybiórczo przytoczone nazwiska - tak językoznawców jak też i filozofów (np. Leibniz, Husserl) oraz w zindywidualizowanym doborze i w indywidualnym omówieniu wybrane tematycznie aspekty ich badań.
} 
wyboru na potrzeby niniejszego tekstu, zależało mi przede wszystkim na ukazaniu wieloaspektowości synergii epistemologicznej, według zasady wspominanej na początku.

Z drugiej strony, na przykład myśliciele tacy jak Karl Bühler czy Algirdas J. Greimas pojawiają się w tej pracy tylko sygnalnie, a szersze opracowanie ich dzieła pod kątem synergii epistemologicznej na pewno zasługuje na osobny raport badawczy. Reasumując: dobór omawianych w tym artykule myślicieli motywowany jest $\mathrm{z}$ jednej strony, ograniczeniem formy i wielkości artykułu naukowego, z drugiej, już opracowanymi przeze mnie tematami, przyszłymi projektami jak również, chęcią zestawienia zróżnicowanych pod wieloma względami perspektyw ${ }^{8}$.

Artykuł ten stanowi również kontynuację tematu, podjętego w mojej monografii (2018), gdzie cały Rozdział I (,Semiotaktyka: postulowana metodologia badawcza semiologii”) został poświęcony refleksji meta-teoretycznej na temat wzajemnych powiazań etnografii (antropologii), nauki o znakach i fonologii, z kluczową postacią Mikołaja Trubieckiego. Zwieńczeniem tej drogi epistemologicznej jest model analizy semiotycznej (zaproponowany przez mnie na scenie naukowej w roku 2009), gdzie adoptuję niektóre osiągniecia fonologii współczesnej do analizy znaków. Zatem w obecnej pracy ten wymiar nie będzie podnoszony. Jak wspomniałam, opracowując tematykę tego tekstu, bazuję zarówno na własnych wnioskach z analizy pierwszorzędowych źródeł (tekstów napisanych przez omawianych myślicieli), jak również zestawiam osiągniecia niektórych historiografów. Tu również oczywiście też trzeba było dokonać wyboru?

Zestawienie zaproponowane poniżej rozpoczyna się od spojrzenia na niektóre aspekty dzieła Mikołaja Kruszewskiego i Ferdynanda de Saussure. Nie jest to i nigdy być nie może opracowanie wyczerpujące - moim celem było zwrócenie uwagi na fakt, że czasem szeroka cytowalność niestety zawęża i stereotypizuje dzieła danych naukowców, i wrzuca w zapomnienie wątki, które często rozwijali równolegle, ale które mniej pasują do narzuconych przez kolejne pokolenia ich sylwetek badawczych. Szczególnie szybko umknął potomności wymiar badawczy ich dzieł, który można by nazwać zgłębianiem świadomości językowej (nie utożsamiany z kognitywistyką).

W następnych sekcjach omawiam również aspekty dokonań uznanych językoznawców, skupiając się na ich mniej 'sztandarowych' dokonaniach, a które uwidaczniają nieuchronne

\footnotetext{
${ }^{8}$ Badania historiograficzne nad synergią można prowadzić wielokierunkowo, na przykład pod kątem samej ikoniczności (zob. np. opracowania w: Simone [1995]).

9 Szczególnie trudnego, jeśli chodzi o uznanych językoznawców, na przykład, można tylko wspomnieć dogłębne badania manuskryptów Saussure'a prowadzone przez Alessandro Chidichimo (2016 inter alia).
} 
nawiązania do wymiaru semiotycznego. Kolejna sekcja poświęcona jest synergicznemu wymiarowi dokonań Charlesa Morrisa, gdzie zwracam uwagę na sieć powiązań z ustaleniami teoretycznymi z innych dziedzin, które zaowocowały teorią wartości i pragmatycznym ukierunkowaniem jego wersji semiotyki. Podobny wymiar badawczy został wskazany w myśli duńskiego językoznawcy Luisa T. Hjelmsleva. Zestawiając przemyślenia dotyczące znaku zawarte w jego dziele Language: An Introduction $\mathrm{z}$ przykładowymi opracowaniami historiograficznymi jego myśli, wskazuję, w jaki sposób teoria fonologii wyłoniła się z jego teorii znaku - wielopłaszyznowych zależności wzajemnych określeń.

Roman O. Jakobson, sam będąc wyjątkowo skrupulatnym historiografem, szczególnie jeśli chodzi o słowiańskich językoznawców, zajmował się również teorią znaku językowego. W sekcji piątej zestawiam niektóre $\mathrm{z}$ jego teoretycznych dokonań w tej dziedzinie, podkreślając związki z poprzednio omawianymi myślicielami. Tu też należy zrobić pewne zastrzeżenie. Żaden myśliciel nie stoi w miejscu, okopując się w „wieży z kości słoniowej” na raz przyjętym stanowisku, ale istotą pracy naukowej jest właśnie ciągła zmiana - można powiedzieć, synergiczna zmiana - udoskonalania, czasem reformulacji a nawet zaprzeczenia swoim pierwotnym ustaleniom (klasycznym przykładem może być wczesny i późny Wittgenstein czy Tomasz Akwinota). W przypadku semiotyki Jakobsona ta zmiana polegała na coraz większym „przychylaniu się” ku perspektywie zaproponowanej przez Charlesa Sandersa Peirce'a. Jednakże dokładne longitudinalne ustalenia w tej kwestii nie mogą być tu wzięte pod uwagę.

W jakiejkolwiek dyskusji na temat synergicznych związków między semiotyką a językoznawstwem nie może zabraknąć postaci Wolfganga U. Dresslera. W kolejnej sekcji przypominam niektóre aspekty jego teorii znaku językowego, bazującej na podstawowych założeniach teorii Peirce’a, jak również przytaczam sposób ich transpozycji na poziom analizy językoznawczej. Zestawienie ma na celu $\mathrm{z}$ jednej strony uwypuklenie zasad analizy językoznawstwa naturalnego, a z drugiej, wykazania jak jeden i ten sam zestaw jakości analitycznych może posłużyć do badania nie tylko różnych zjawisk w ramach jednego modułu, ale i różnych modułów ${ }^{10}$.

Dwie ostatnie sekcje poświęcone są językoznawcom/semiotykom mniej znanym w głównym nurcie językoznawstwa, ale którzy w znacznym stopniu przyczynili się do pogłębiania jego siły wyjaśniającej - Julii Kristevy oraz Yishaia Tobina. Można powiedzieć, iż Kristeva

10 Zgodnie z wytycznymi np. Tobiasza Scheera (2007) zalecającego, aby nie namnażać ad libitum nieskończonej ilości jednostek analitycznych, często wymyślanych po to tylko, aby opracować dane zjawisko językowe. 
była sama $\mathrm{w}$ pewnym sensie synergicznym łącznikiem między różnymi szkołami językoznawczymi, zapoznając akademię Europy zachodniej z dokonaniami słowiańskiego językoznawstwa (w szczególności Michaiła Bachtina). W części jej poświęconej skupiam się na szerokim ujęciu języka w jej myśli, i na psychoanalitycznym rozumieniu semiotyczności. Badania Yishaia Tobina stanowią przykład synergii na wielu poziomach. Przede wszystkim, zajmuje się on projektem 'fonologia jako zachowania ludzkie', gdzie bazuje na danych klinicznych przetwarzania mowy. Ponadto, specjalizując się w izraelskim języku migowym i jego symbolice, wskazuje na inherentną wielowarstwowość i semiotyczną stronę komunikacji. $\mathrm{W}$ tej pracy zajmuję się jego własnym modelem komunikacyjnym, bazującym na funkcjonalizmie strukturalizmu praskiego.

\section{System wartości i asocjacje w dziele Mikołaja Habdanka Kruszewskiego i Ferdynanda de Saussure'a}

Owo „osobiste” spojrzenie na semiotykę znaku językowego zacznę od przytoczenia dokonań językoznawcy, który być może najbardziej zrewolucjonizował swoją dziedzinę, i którego prace, jak zauważają Roman O. Jakobson (1973) i Joanna Radwańska-Williams (1993), stały się podwaliną kierunku reprezentowanego następnie przez (wczesnego) Jana Baudouina de Courtenay i przez samego Ferdynanda de Saussure'a, a który, dotkliwie naznaczony przez los, został prawie zapomniany już niedługo po swojej przedwczesnej śmierci: Mikołaja Habdanka Kruszewskiego (1851-1887) ${ }^{11}$. Sprawa wpływu Kruszewskiego, czy raczej genialnego przeniesienia osiągnięć psychologii (szczególnie jeśli chodzi o asocjacje) i logiki (szczególnie Johna Stuarta Milla), wbrew całemu ówczesnemu światu językoznawczemu ${ }^{12}$ do stworzenia wersji językoznawstwa, jaką znamy dzisiaj, jest na pewno bezsporna, aczkolwiek mało znana szerokiemu gronu czytelników ${ }^{13}$.

11 Inspirujący przegląd i opracowanie dokonań Kruszewskiego, jak również dokładną bibliografię, czytelnik znajdzie np. w: Radwańska-Williams (1993, 2000); Jakobson (1971, 1973).

12 Wersję niemieckojęzyczną wstępu do swojej pracy na temat guna Kruszewski opublikował na własny koszt w roku 1881, pod tytułem „Über die Lautabwechsung” (Kazan 1881), ponieważ czasopisma niemieckie odmówiły jej publikacji pod pretekstem, że 'zajmuje się bardziej metodologią niż językoznawstwem' (Jakobson 1993: 254).

13 Początki europejskiego strukturalizmu próbuje rozwikłać np. Keith Percival. W swoim artykule (2011) cytuje on m. in. urywek z listu, który otrzymał od Edwarda Stankiewicza (datowany na 7 października 1977): 'Nie mam najmniejszej wątpliwości, że zarówno Trubecki jak i Jakobson celowo starali się przypisać całą zasługę [stworzenia] strukturalizmu Saussure'owi (z którym mieli niewiele wspólnego), a ograniczyć rolę B[audouina] d[e]C[ourtenay], (od którego wzięli bardzo dużo). Niedawno zapytałem Jakobsona prosto z mostu, dlaczego [prażacy] nie wyrazili jaśniej znaczenia B d C i Kruszewskiego, i odpowiedział: 'nikt by nas nie słuchał, gdybyśmy mówili o Polakach" (Percival 2011: 252). Patrz szerzej na ten temat w pracy Haładewicz-Grzelak (2013). 
W przedmowie do anglojęzycznego wyboru pism Kruszewskiego, Ernst F. K. Koerner zauważa, że ten językoznawca wprowadził już w swoich pracach z początku lat 1880 . najistotniejsze założenia dotyczące arbitralności znaku językowego, które później znajdziemy w pełni rozwinięte $\mathrm{w}$ myśli Ferdynanda de Saussure ${ }^{14}$. Jedną z takich kanonicznych tez odnotowanych przez Koernera jest założenie, że słowo rozumiane jako znak językowy jest wynikiem połączenia części nośnej (na przykład realizacji wokalnej) z częścią przedstawieniową (semantyczną), nazwaną przez Kruszewskiego „symbolem”. Realizacja wokalna jest drugorzędna, na przykład u głuchoniemych przebiega ona poprzez gest (Koerner 1995: XXV). Oczywiście obecnie tego typu twierdzenia stanowią już podstawowy kanon, ale należy przypomnieć za Koernerem niezaprzeczalny fakt wprowadzenia ich na scenę naukową przez Kruszewskiego we wczesnych latach 1880.

Jeśli chodzi o sposób połączenia tych dwóch jakości w umyśle ludzkim ${ }^{15}$, Koerner (1995: XXVI-XXVII) podkreśla, że Kruszewski stosuje przetransponowane prawa asocjacji Johna Stuarta Milla, w szczególności prawo podobieństwa i prawo równoczesności, czy natychmiastowego następnika wyłożone w jego pracy Logika. Kruszewski proponuje dwa zasadnicze typy relacji: asocjacje podobieństw i asocjacje przyległości. Im mniejszy stopnień asocjacji poszczególnych leksemów, tym łatwiej zostają one zapomniane. 'Jeśli przypomnimy sobie, że Saussure mówił o relacjach asocjacyjnych (zamiast relacji pragmatycznych jakby to ujęli Hjelmslev i Firth), możemy przypuścić, że mamy tutaj w propozycjach Kruszewskiego bezpośrednie źródło saussure'ańskich syntagmatycznych / asocjacyjnych dychotomii w języku' (Koerner 1995: XXVI-XXVII).

W swoim majstersztyku historiograficznym (1993) Radwańska-Williams rozpatruje oeuvre Kruszewskiego, przedstawione głównie w książce Очерк науки о языке (1883) jako 'zaginiony paradygmat' ('paradigm lost') - który miał pełen potencjał, aby stać się kanonem językoznawstwa, co najmniej na równi z Kursem. Porównanie tym bardziej zasłużone biorąc pod uwagę fakt, iż Saussure doskonale zaznajomiony był z chronologicznie wcześniejszymi pracami Kruszewskiego (Radwańska-Williams 1993: 2). Badaczka wychodzi z założenia, iż

ścisły związek między przeszłością a teraźniejszością w teorii językoznawstwa odzwierciedla naturę językoznawstwa jako nauki. Podczas gdy metodologia lingwistyczna jest zorientowana na opis gramatyki, to filozoficzne podstawy teorii lingwistycznej zajmują się kwestią natury języka.

\footnotetext{
${ }^{14}$ Oraz, jak zauważa Joanna Radwańska-Williams (1993: 158 i nast.), w pracach Romana O. Jakobsona, w szczególności uwypuklenie psychologicznej strony języka (Radwańska-Williams 1993: 164).

${ }^{15}$ Należy tu przypomnieć, że dla Kruszewskiego słowa istnieją tylko w umyśle (patrz Koerner 1995: XXVI), czyli można wywnioskować, że daje on pierwszeństwo mentalnej stronie mowy.
} 
Odpowiedź teorii na to pytanie stanowi jej filozoficzne przesłanki i ma głębokie implikacje dla późniejszej metodologii.

W szczególności zwraca ona uwagę na dwa aspekty pracy Kruszewskiego, które stały się podstawą późniejszej krytyki Jakobsona nakierowanej na pracę Saussure’a: stwierdzenie czynnej roli społeczności mownej jak i pomysł ujęcia zmiany językowej jako 'historii systemu fonemicznego ([E]. history of the sound system; Radwańska-Williams 1993: 161). Zaginiony paradygmat Kruszewskiego to zatem przykład synergii par excellence: opracowanie psychologicznych podstaw metodologicznych i zastosowanie ich do zgrupowania praw językowych na bazie mentalnego aspektu języka. Stały się one potem dla Jakobsona bazą badań nad afazją i jego teorii metafory (Radwańska-Williams 1993: 166).

Wkład Ferdynanda de Saussure’a (1856-1913) w rozwój semiotyki i językoznawstwa, zawarty w wersji wydanej jako Kurs językoznawstwa ogólnego jest chyba najszerzej cytowanym i omawianym dokonaniem językoznawczym na świecie, dlatego w niniejszym opracowaniu nie zajmę się dokładniej tym dziełem. Natomiast chciałabym przywołać semiotyczny wymiar innej pracy autorstwa „maître genevois”, która w odróżnieniu od Kursu, zdążyła popaść w zapomnienie.

Jedyne dzieło książkowe, jakie Saussure osobiście zaaprobował i przedłożył do druku, ukazało się w 1879 w Lipsku pod tytułem Mémoire sur le système primitif des voyelles dans les langues indo-européennes ${ }^{16}$. Owa monografia wydana przez 21-letniego Ferdynanda de Saussure sprowokowała ostre retorty ze strony jego starszych kolegów (i ówczesnych nauczycieli), głównie Hermanna Osthoffa i Karla Brugmanna, co zauważają zarówno Jakobson (1973: 289) jak i Paul Bouissac (2010); i uczyniła z młodego studenta buntownika wśród ówczesnego już wysoce ikonoklastycznego środowiska młodogramatyków ${ }^{17}$. Aby odeprzeć ich zarzuty, Saussure zaczął pisać studium fonetyczne, w zamierzeniu mające stanowić tylko

${ }^{16}$ Na przykład źródło Wikipedia pod hasłem Ferdynand de Saussure jeszcze w 2019 roku podawało, iz „Saussure za życia nie wydał żadnej książi”. (Por.: http://pl.wikipedia.org/wiki/Ferdinand de Saussure. Data ostatniego dostępu 22-02-2019]). Obecna wersja opisu z tego popularnego źródła już zawiera wzmiankę o Mémoire.

${ }^{17}$ Szeroko na ten temat pisze Bouissac (2010). Pomijając ostre ataki starszych kolegów Saussure'a, jak zaważa ten badacz, monografia była raczej ignorowana w kręgach młodogramatycznych. Jednakże przytacza on też anegdotę, że gdy młody Saussure przedstawił się niemieckiemu specjaliście, u którego miał zamiar studiować, ten zapytał go 'czy przypadkiem nie jest krewnym tego sławnego językoznawcy szwajcarskiego, który napisał Mémoire' (Bouissac 2010: 47). Patrz szerzej: Haładewicz-Grzelak (2014). Mémoire szeroko omówiona jest w tekstach zawartych w Cahiers Ferdinand de Saussure (1978) tom 32, między innymi przez Jerzego Kuryłowicza (1978). 
wyjaśniającą notatkę z dziedziny badania sylaby indoeuropejskiej (Jakobson 1973: 289) ${ }^{18}$. Jak to miało miejsce z większością prac Saussure'a (,suivant son habitude”), notatka nigdy nie pojawiła się w żadnym wydawnictwie, i obecnie istnieje tylko w formie manuskryptu. Z punktu widzenia tematyki istotnej dla niniejszych rozważań ta wczesna, niepublikowana praca młodego Szwajcara zawiera kluczowe spostrzeżenia dotyczące semiologicznej natury fonemu, które poniżej streszczę w moim tłumaczeniu za Jakobsonem (1973).

Semiologiczna natura fonemu zawiera się $\mathrm{W}$ następującym schemacie: zjawisko fizjologiczne $\rightarrow$ zjawisko fizyczne $\rightarrow$ doznanie, gdzie 'dodatkowa strzałka wskazuje efekt albo ostateczny cel zwany ideq' (Jakobson 1973: 292). Następnie Saussure spisuje równoważności definicyjne: fonem $=$ opozycje akustyczne; fonem $=$ niepodzielność dźwięku w czasie - rezultat relacyjnego podobieństwa; fonem = całość dźwięku postrzeganego $\mathrm{w}$ jednym momencie. Po prawej stronie tego równania semiologicznego, jak dalej zauważa Jakobson (1973: 292), Saussure wprowadza dodatkową definicję: fonem: doznanie, które prowadzi wolę „,[Phonème: impression [barré: sensation] directrice de la volonté]", a jeszcze dalej, w kolejnej próbie, 'fonem = zjawisko pośrednie, rozważane jednocześnie w swoim odniesieniu do doznania, jak i do aktu fizjologicznego' (Jakobson 1973: 292). Podkreślenie czysto semiologicznych wartości fonemu prowadzi Saussure'a do założenia, iż przy analizie różnych fonemów w jakimkolwiek języku trzeba przede wszystkim znaleźć kryterium różnicujące - „différenciateur/ déterminateur" (Jakobson 1973: 292).

$\mathrm{Z}$ tej myśli z kolei wyłania się następne kryterium analityczne, a mianowicie uznanie podstawowego znaczenia czynników negatywnych w klasyfikacji fonemów (Jakobson 1973: 293). Co za tym idzie, 'wszystko, co w języku jest sprawą świadomości, czyli odniesienie między dźwiękiem i jego ideą, wartość semiologiczna fonemu, może i powinno być badane poza wszelkimi rozważaniami historycznymi’ (Jakobson 1973: 294). Na przykład relacja między wariantami sonantycznymi i konsonantycznymi dźwięków takich jak płynne (/l, r/) zostaje nazwana 'równoważnością semiologiczną' (équivalence sémiologique). W ten sposób, jak stwierdza Jakobson, Saussure inauguruje, nazywa i opisuje nową dyscyplinę - fonetykę

18 'Jak deklaruje sam Saussure, tekst „był pierwotnie jedynie notą wyjaśniającą, przeznaczoną do badania sylaby indoeuropejskiej”, ale stopniowo przekształcił się w długą i szczegółową dyskusję na temat sonantów i spółgłosek indoeuropejskich z szerokimi dygresjami na zasadnicze pytania fonetyki ogólnej' Jakobson (1973: 289). Tu można tez wspomnieć o innym nieopublikowanym manuskrypcie Saussure'a, określonym przez Jakobsona jako „enfantillage”, który Saussure napisał mając 15 lat: Essay pour réduire les mots du grec,du latin, de l'allemand à une petit nombre de racins, przedrukowany in extenso w: Cahiers Ferdinand de Saussure (1978) Vol. 32; 73-101. Esej zawiera m.in. opis regularności prowadzących do odkrycia nasalis sonant - dźwięku, który oficjalnie przedstawił akademii Karl Brugmann dopiero dekadę później (zob. szerzej na ten temat: HaładewiczGrzelak (2013, 2014, 2015). 
semiologiczną, która zajmuje się dźwiękami i ich ciągami dźwięków w językach w cyklu akustyczno-psychologicznym, czyli jeśli mają one wartość dla pojęć (Jakobson 1973: 295) ${ }^{19}$.

Echa tego podejścia przewijają się w wydanych notatkach mistrza z Genewy (2004), stając w wyraźnym kontraście z wersją opracowaną przez Charlesa Bally’ego i Alberta Sechehaye’a. $\mathrm{Na}$ przykład, wprowadzając pojęcie 'sem' i wydzielając aposem i parasem jako pojęcia podstawowe, Saussure stwierdza: „sądzę, że w mowie dyskursywnej można mówić o parasemach (figurach dźwiękowych)" (Saussure 2004: 110 [3311.2 item]). Co więcej, myśliciel ten widzi konieczność wprowadzenia kategorii, którą nazywa „aposemem mentalnym”, co stawia go bardzo blisko wobec teorii triadycznych znaku:

[3312.1 item] Znak aposem. Jeśli tylko powstaje gdzieś problem języka, natychmiast pojawia się slowo i znaczenie (lub znak i znaczenie), jakby do tego się wszystko sprowadzało, a ponadto zawsze podawane są przykłady nazw: drzewo ${ }^{20}$, kamień, krowa - takich, jakie Adam nadawał [... ] to znaczy, wszystko to, co w semiologii jest najgrubsze, chodzi tu więc o takie wypadki, w których jest ona [...] po prostu nomenklaturą, to znaczy, takie wypadki, w których w psychologicznym kojarzeniu semu ujawnia się niezaprzeczalnie trzeci element, świadomość tego, że odnosi się on do pewnego zewnętrznego bytu wystarczająco w sobie określonego, by wymykać się działaniu ogólnego prawa znaku.

(Saussure 2004: 111)

Kurs językoznawstwa ogólnego Saussure'a, uznany za kanon opisu strukturalistycznego, od początku budził kontrowersje wśród jemu współczesnych. Tu można przytoczyć nazwisko takie jak (wczesny) Roland Barthes, który, jak wielu semiotyków i językoznawców po nim, budował swoją teorię w opozycji do Saussure’a, w szczególności do Kursu, gdzie rzeczywiście badanie językoznawcze większych jednostek narracyjnych nie zostało uwzględnione. Jednakże na przykład Sungdo Kim (1993: 17) przytacza cytat z listu Saussure'a do Antoine'a Meilleta z roku 1894, w którym mistrz z Genewy stwierdza, że badanie języka nie przynosiło mu żadnej przyjemności z powodu jego abstrakcyjnej natury. Jednocześnie wyznaje chęć badania strony etnograficznej języka, wypowiadając się o jego 'malowniczej' naturze ${ }^{21}$. Powyższy cytat

${ }^{19} \mathrm{Na}$ ten temat w Kursie czytamy, co następuje: „Język bowiem jest systemem opartym na opozycji psychicznej owych wrażeń akustycznych, podobnie jak haft jest dziełem sztuki powstałym dzięki opozycji wzrokowej między nitkami różnego koloru; otóż tym, co ma znaczenie dla analizy jest gra tych opozycji a nie sposób, w jaki otrzymano kolory" (Saussure 1961[1916/1955]: 48). Zob. szerzej Haładewicz-Grzelak (2015).

${ }^{20}$ Tu niestety z ubolewaniem przychodzi mi skonstatować wyjątkową ironię dziejową: właśnie leksem 'drzewo' stał się kanonem wyjaśniania saussure'ańskiej dwubiegunowości znaku.

${ }^{21}$ Saussure określa to uczucie w następujących słowach: „C'est en dernière analyse seulement le côté pittoresque d'une langue, celui qui fait qu'elle diffère de toutes les autres comme appartenant à un peuple ayant 
związany jest z tzw. semiologią mitograficzną Saussure'a, którą Kim 1993 (patrz też: Gandal 1997) szczegółowo analizuje, i niektóre z jego ustaleń przytoczę poniżej.

Wśród dwudziestu czterech woluminów manuskryptów autorstwa Saussure'a, przechowywanych w zbiorach Bibliothèque Publique et Universitaire de Genève (B.P.U.), dwa poświęcone są badaniom tzw. legendy Nibelungów. Jak zauważa Kim, fakt, że Saussure prowadził prace nad mitologią germańską jednocześnie z rozwijaniem wykładów na temat językoznawstwa ogólnego, stanowi pewien problem dla historiografów: często uważa się, że badanie legendy i epopei o Nibelungach stanowiło nieistotną, przypadkową rozrywkę Saussure'a, albo klasyfikowano te badania jako tzw. 'drugi Saussure', czyli jako pewne rozdwojenie jego poglądów, bez żadnego związku z myślą zawartą w Kursie - tym bardziej, że w całym Kursie nie ma najmniejszego śladu tych badan; ani słowo „legenda”, ani „symbol” ani razu nie występują ${ }^{22}$. Badania Kima wskazują jednak, iż można znaleźć wspólny mianownik, rozszerzając (otwierając) semiologię saussure'ańską. 'W rzeczy samej, Saussure próbował opracować semiologię opowieści biorąc legendę germańską jako domenę zastosowania swojej nowej semiologii, której program zawarł w Kursie' (Kim 1993: 11) 23.

Praca Kima odsłania nam wiele nowych aspektów całości oeuvre Saussure’a. Na przykład, trzecia część planowanej przez mistrza z Genewy książki, zatytułowana „Mitografia i semiologia”, zawierać miała, według spisu podanego przez Kima, między innymi podrozdział o następujących częściach: Język i mit. 1) tożsamość symbolu legendy i symbolu językowego; 2) gramatyka opowieści legendarnej; 3) W kierunku semiologii opowieści (Kim 1993: 14). 'Skoro Saussure świadomy jest faktu, że legenda stanowi jeden z modułów języka semiologicznego, jego mitografia przenosi się na operacjach, jakie mit instytuuje wychodząc z ugruntowania historycznego' (Kim 1993: 26). Te operacje polegają na transformacjach usytuowanych w szerszym schemacie komunikacji, które Kim dzieli na trzy kategorie: redukcje, czyli sytuację, gdy obiorca traci część oryginalnych treści nadawcy (tu można wyszczególnić dalej relacje

certaines origines, c'est ce côté presque ethnographique qui conserve pour moi un intérêt: et précisément, je n'ai plus le plaisir de pouvoir me livrer à cette étude sans arrière-pensée et de jouir du fait particulier tenant ä un milieu particulier (Ms. fr. 3957-6)" (Kim 1993: 17).

${ }^{22}$ Gandon (1997: 174) używa nawet określenia typu 'dyskurs Doktora Jekylla/ Mr Hyde'a' przeciwstawiający 'profesorowi genewskiemu' jego ciemną stronę „le côté nocturne de Ferdinand', „le Saussure marseillais et honteux" (Gandon 1997: 174).

${ }^{23}$ Dla ilustracji podaję tu przykład transkrypcji jednej z notatek z pracy Saussure’a o legendzie Nibelungów za Gandonem: „Au bout de quelques temps... [la rune I, F. G.] est la dixième de l'alphabet... Mais ici déjà ELLE commence a supposer unité: que. Où est maintenant l'identité? On répond en général par sourire comme sans [barres] [en marge: si c'était une chose curieuse] remarquer la portée philosophique de la chose, qui ne va à rien moins que de dire que tout symbole, une fois lancé dans la circulation - même dans l'incapacité absolue de dire en quoi consistera son identité à l'instant suivant (Saussure 1904-1910: 3958, IV, f Ir)"' (Gandon 1997: 178). 
metaforyczne i metonimiczne $)^{24}$, amplifikacje, co oznacza takie zmiany w signifiant, przez które powstaje nowy znak; a trzecia kategoria to zwykły błąd przekazu (Kim 1993: 31 i nast.) ${ }^{25}$. Owo szersze spojrzenie na semiologię zanalizowane przez Kima i wsparte licznymi cytatami mistrza z Genewy jasno wskazuje, że szwajcarski myśliciel od początku swojej drogi naukowej przywiązywał ogromną wagę do badania języka w szerszym środowisku znakowości ludzkiej (Kim 1993: 38). Co więcej Kim nawet konkluduje, że to głównie dzięki badaniom mitograficznym, rozwijanym równolegle z wykładami zapisanymi jako Kurs, możliwe było wyłożenie teorii semiologicznej: 'Wydaje mi się, że mit był pierwszym sprawdzianem zastosowania jego semiologii' (Kim 1995: 74).

\section{Wymiar procedur logicznych znakowości w pracach Charlesa Morrisa}

Istotny wkład $\mathrm{w}$ teoretyzowanie formalnych zależności między językiem a znakami wniósł Charles Morris (1901-1979), choć skierował on rozwój semiotyki językoznawczej w kierunku diametralnie odbiegającym od poprzednio omawianych prac. Do napisania swojej książki o znakach, jak wspomina w jego obituarium Charles Hartshorne (1978: 193), Morris dokładnie zapoznał się z dziełami zebranymi Peirce'a. Hartshorne również nadmienia, że Peirce współpracował z Rudolfem Carnapem, był studentem George’a Herberta Meada i redaktorem

\footnotetext{
${ }^{24}$ Arrivé (cytowany w Kim 1993: 31) widzi analogię między metonimią legendy a przemianami dźwięku: 'tak więc metonimia, która redukuje bitwę dwóch armii do bitwy dwóch wodzów wyjaśnia się (naturalnie) poprzez przemiany diachroniczne, w ten sam sposób co w Kursie (dźwięki ulegają przekształceniu w czasie) (1986: 35)' (Kim 1993: 31).

${ }^{25}$ Co ważne, Kim wielokrotnie podkreśla zasadniczą asymetrię między teorią znaku z Kursu a teorią wyłaniającą się z manuskryptów o legendzie. Asymetria polega m. in. na tym, że ani słowo legenda, ani żaden inny wątek, rozwijany przecież przez Saussure'a równolegle w czasie do wykładów z językoznawstwa ogólnego, nie pojawia się w Kursie. Jednakże, należy zwrócić tu uwagę, iż Bouquet - Engler, w przedmowie do wydania Szkiców z językoznawstwa ogólnego piszą kontrowersyjnie, że:[jeśli zaś chodzi o ugruntowanie - epistemologiczne i filozoficzne- refleksji genewskiego mistrza prezentowanych w Szkicach], to odpowiada ona dokładnie dwóm nurtom jego myśli mocno zaniedbanym przez 'wydawców' (tym mianem właśnie określają siebie, co ciekawe, Bally i Sechehaye w przedmowie do książki, którą od początku do końca sami zredagowali)" (Bouquet - Engler 2004 [2002]: 26). Bouissac podobnie zauważa, że choć Charles Bally i Albert Sechehaye uczęszczali na niektóre z wykładów Saussure'a z gramatyki porównawczej, 'nie byli obecnie na żadnym z trzech kursów językoznawstwa ogólnego, które Saussure prowadził między 1906 i 1911 . Zatrudnili dawnego studenta, Alberta Riedlingera, aby pomógł im posortować materiał i zbudować zadowalającą rekonstrukcję na bazie tych notatek. To było tym większe wyzwanie, iż Saussure nie organizował wszystkich trzech kursów w ten sam sposób' (Bouissac 2010: 117). Co ważniejsze obydwaj 'redaktorzy' mieli drastycznie różne podglądy od tych, które przypisali Saussure'owi w Kursie. U Percivala znajdziemy cytat z wykładu inauguracyjnego Bally’ego (następcy Saussure'a na stanowisku profesora w 1913). Z cytatu wynika, że choć Bally rozpoczął wykład przez pełne szacunku omówienie paradygmatu teoretycznego opracowanego przez Saussure'a, następnie 'otwarcie stwierdził, że sam doszedł do innych konkluzji niż jego mistrz' (Percival 1981: 42). Z powyższego może wynikać, że wąski pogląd na semiologię i arbitralność znaku, prezentowany w Kursie może nie od końca odpowiadać rzeczywistemu podejściu Saussure'a.
} 
jego wydanych pośmiertnie dzieł zebranych. Kanoniczne poziomy relacji międzyznakowych według Morrisa różnią się jednak znacznie od semiotyki Peirce’a:

syntaktyka bada relacje składniowe zachodzące pomiędzy znakami, niezależnie od relacji zachodzących pomiędzy znakami a obiektami lub ich interpretatorami. Semantyka zajmuje się relacją pomiędzy znakami a ich desygnatami, czyli obiektami, które denotują lub mogą denotować. Jako „pragmatykę” ustanawia się naukę badającą relacje zachodzące pomiędzy znakami a ich interpretatorami.

(Morris 1938: 30, cyt. za: Stalmaszczyk 2008: 13) ${ }^{26}$

Jak zauważa następnie Piotr Stalmaszczyk (2008: 14), jest to tzw. semiotyczna teoria pragmatyki i choć Morris rozwijał swoje teorie dla potrzeb semiotyki, znalazły one szeroką kontynuację na płaszczyźnie typowo językoznawczej, za udziałem naukowców takich jak np. Robert Stalnaker czy Richard Montague.

Stalmaszczyk (2008: 13) podkreśla również, że teoria Morrisa została spopularyzowana na gruncie filozofii i filozofii języka przez Rudolfa Carnapa, zwłaszcza w pracy Introduction to Semantics, gdzie niemiecki filozof wyszczególnia trzy aspekty użycia języka, tj. mówiącego, następnie wypowiedziane wyrażenie oraz desygnat tego wyrażenia (Stalmaszczyk 2008: 13). W semiotyce, rozumianej jako ogólna teorii znaków i języków, w związku z tym, jak podkreśla Stalmaszczyk, Carnap wydziela trzy obszary badawcze. W wypadku, gdy badania języka zawierają odniesienia do mówiącego, należą one do dziedziny pragmatyki. Jeśli skoncentrowane są na odwołaniach do desygnatów, ale nie do osób mówiących, są to badania semantyczne. Trzeci zakres obejmuje sytuację, gdy analizowane są jedynie wyrażenia, z pominięciem mówiących oraz desygnatów (Carnap [1942]: 17; cyt. za|: Stalmaszczyk 2008: 13). Co więcej, Carnap określa językoznawstwo jako deskryptywną i empiryczną część semiotyki - zarówno w od niesieniu do mówionych jak i pisanych języków (Carnap 1942: 13; cyt. za: Sebeok 1994: 109) ${ }^{27}$.

${ }^{26}$ Właśnie te propozycje teoretyczne cytują też Osgood et al. (w późniejszym wydaniu), stwierdzając, że w swoich badaniach przyjmują klasyfikacje Morrisa, nazywając relacje znaków do sytuacji i zachowań znaczeniem pragmatycznym (socjologicznym), a relacje znaków do innych znaków znaczeniem syntaktycznym (językowym) (Osgood et al. [1957]196: 43). W pracy Morrisa (1964) pragmatyka określana jest w szczególności jako 'aspekt semiotyki zajmujący się pochodzeniem, użyciem i efektami znaków' (Morris 1964: 44).

${ }^{27}$ Semiotyczna logika znaku językowego była już zresztą rozwijana w XVII w.. Na przykład, dominikanin John Poinsot (John of Saint Thomas) twiedził m. in., że „sign is equivalent, in all that concerns experience, with being itself as anterior to any division of being into ens quod est extra and ens quod est intra animam (that is, ens reale and ens rationis)" (Deely 1988: 33). 
Kolejny aspekt synergii w myśli Morrisa uwypuklają Charles Osgood, George Suci i Percy Tannenbaum stwierdzając, że choć 'Morris, jako filozof wyszkolony został w tradycji Peirce'a i innych pragmatyków amerykańskich, staje się jasne w jego ostatniej pracy Signs, Language and Behaviour (1946), że odczuwa on potrzebę zakotwiczenia teorii znaczenia do zachowania używających znaki organizmów. Aby rozwijać ten cel, pracował z dwoma znamienitymi teoretykami behawioryzmu, Tolmanem i Hulle' (Osgood et al. [1956] 1967: 75).

Dla niniejszego zakresu tematycznego bardzo ważną pozycją jest Morris (1964) - książka poświęcona relacjom znaków i wartości. We wstępie Morris podkreśla swoje szerokie rozumienie semiotyki, określając jej cel, jako 'ogólną teorię znaków i ich przejawów, zarówno wśród ludzi jak i zwierząt, zarówno normalnych jak i patologicznych, zarówno językowych jak i niejęzykowych, osobistych i społecznych. Semiotyka jest, więc przedsięwzięciem międzydyscyplinarnym’ (Morris 1964: 1). Samą semiozę Morris postrzega jako relację między pięcioma terminami: $v, w, x, y, z$, gdzie ' $v$ ustawia $\mathrm{w} w$ dyspozycję do działania $\mathrm{w}$ określony sposób, $x$, wobec danego rodzaju obiektu, y, pod warunkami z' (Morris 1964: 2). Jest to oczywiście model bazujący na założeniach semiotyki Peirce’a - jak dalej objaśnia Morris, w-y to ,interpretatorzy”, a $x$-y (iksy) to ,interpretanci”, $v$-y to znaki, a $y$-i (igreki) to znaczenia. Bazując na teorii aktu Meada i terminologii psychologicznej, Morris sugeruje, że znaczenie (signification) jest trójwymiarowe, wobec czego dzieli znaki na: desygnatowe, oceniające i preskryptywne. W każdym z tych wymiarów znaczenia zdarzają się inne typy interpretantów: na przykład, w wypadku znaku ewaluacyjnego, interpretant będzie dyspozycją działania wobec danego przedmiotu według kryterium satysfakcjonujący - niesatysfakcjonujący (Morris 1964: $6)$.

Semiotyczna strona teorii Morrisa została pokrótce zaprezentowana przez Thomasa Alberta Sebeoka (1920-2001), który stwierdza między innymi, że:

[wśród filozofów] Charles Morris (1946: 220-3; 1964: 60-2) wydaje się być najbardziej przezorny odnośnie powiązań semiotyki i językoznawstwa. W 1946 zasugerował - co dobrze pamiętam też z jego seminariów sześć lat wcześniej - że semiotyka powinna zapewnić „metajęzyk dla językoznawstwa”, i w ten sposób terminologia językoznawcza byłaby zdefiniowana w terminach semiotycznych. Szczegółowe wykonanie tego programu oznaczałoby wyłonienie się semiotycznie ugruntowanej nauki językoznawczej.

(Sebeok 1994: 108)

Morris rozszerzył wyżej wspomnianą propozycję Carnapa, poprzez wprowadzenie pojęcia lansign system - systemu znakowo-językowego, który mógłby być stosowalny nie tylko do 
mówionych czy pisanych języków, ale również do logiki symbolicznej, matematyki czy nawet do sztuki (Sebeok 1994: 109).

Oczywiście nie brakuje i głosów krytycznych wobec jego myśli. Na przykład, według Anny Wierzbickiej (1999: 49), Morris chciał odseparować związki pomiędzy znakami a rzeczywistością od związków zachodzących między znakami a ich użytkownikami. Jednakże, jak podkreśla dalej Wierzbicka, ponieważ w języku naturalnym same środki składniowe i morfologiczne, jak też i illokucyjne same w sobie są nośnikami znaczenia, dlatego wprowadzony przez Morrisa podział nauki o znakach na semantykę, składnię i pragmatykę sprawdza się głównie w przypadku języków sztucznych. W przypadku języka naturalnego, znaczenie jest subiektywne i antropocentryczne, odbijające ludzką interpretację świata. Zatem znaczenie „W różnym stopniu odzwierciedla panujące w danej kulturze sposoby ujmowania rzeczy i zjawiska oraz charakterystyczne dla niej modele integracji społecznej, co obiektywne cechy, świata 'takiego, jaki jest” (Wierzbicka 1999: 49-50).

Reasumując zagadnienie synergii w pracy Morrisa, należy zwrócić uwagę, na: 1) fakt, że sam Morris podkreśla, że dziedzina semiotyki zasadza się na interdyscyplinarności; 2) w opracowaniu swojej teorii korzystał on z dokonań filozofów, behawiorystów, psychologów jak również z już uznanych prac Peirce’a. Jeśli chodzi o kierunkowość przenikania się dziedzin językoznawstwa i semiotyki (semiologii), jak wynika z reminiscencji Sebeoka, Morris, podobnie jak później Wolfgang U. Dressler (patrz sekcja 6), stał po stronie uznania semiotyki jako meta-teorii dla językoznawstwa) ${ }^{28}$.

\section{Różnicujące poziomy między formą a substancją w myśli Louisa Trolle Hjelmsleva}

Dzieło Louisa Trolle Hjelmsleva (1899-1965) - wydane po wielu latach od napisania (1970) Language: An Introduction w duńskim oryginale: Sproget: En introduktion, zawiera rozdział zatytułowany Sign formation (tworzenie znaku) ${ }^{29}$. W rozdziale tym naukowiec wyszczególnia najważniejsze typy tworzenia znaków (form wyrazowych), jako 'funkcjonalne przekształcenie znaków’ (np. działanie elementów, dysymilacja, metateza, haplologia, kontaminacja, etc.), co jak można zauważyć, stanowi przykłady przekształceń obecnie ukonstytuowanych jako

${ }^{28}$ Można też tu przypomnieć podobne kontrowersje wynikłe w obszarze filozofii. Na przykład, jeśli chodzi o Husserla, jego celem nie była 'matematykalizacja' filozofii, ale właśnie uczynienie filozofii meta-teorią dla nauk ścisłych (Olga Louchakova-Schwartz, przekaz osobisty, maj 2020).

29 Terminologiczne „vicissitudes” przy kolejnych tłumaczeniach dzieł duńskiego językoznawcy przybliża Alessandro Zinna (2017). 
kanoniczne procesy fonologiczne. Dla Hjelmsleva zatem fonologia była niezaprzeczalnie formą nauki o znakach i znakowości ${ }^{30}$.

Jeśli chodzi o same teorie semiotyczne tego naukowca, ogólne wprowadzenie znajdziemy we wczesnej twórczości Rolanda Barthesa (1987: 17), który podkreśla, że Hjelmslev nie zarzucił saussurre'ańskich pojęć language / speech (język/mowa), ale rozparcelował te terminy w sposób bardziej formalny, rozróżniając, w ramach samego języka, jeszcze ciągle w opozycji do aktu mowy, trzy poziomy: i) schema (schematy), to jest język jako czysta forma (language u Saussure'a); na przykład francuskie $r$ zdefiniowane fonologicznie; ii) norma, czyli język, jako materialna forma 'po zdefiniowaniu poprzez pewien stopień społecznej realizacji, ale ciągle niezależny od tej realizacji', na przykład francuskie $r$ zrealizowane w jakikolwiek sposób w mowie; iii) użycie, rozumiane jako zestaw zwyczajów przeważający w danej społeczności, czyli poprzednio przytoczone $r$ wymówione w konkretnym dialekcie.

Jak dalej nadmienia Barthes, z powodu wielopłaszczyznowych zależności wzajemnego określania się przez te trzy poziomy, Hjelmslev otrzymuje w zasadzie dwa główne poziomy współzależności. Pierwszy według Barthesa to schemat, którego teoria scala się z planem z językowej instytucji i który wiąże się z formą. Drugi plan stanowi grupa język - użycie - mowa, i jej teoria z kolei łączy się z teorią substancji i wykonania. Ponieważ, według Hjelmsleva norma jest czystą metodologiczną abstrakcją, a mowa pojedynczą konkretyzacją ('przejściowy dokument'), otrzymujemy 'nową dychotomię schemat /użycie, która zastępuje saussure'ańską parę language / speech' ([1964] 1987: 18) 31. Wąsik (1997: 40) podkreśla, że w ten sposób Hjelmslev, choć programowo nawiązuje do Saussure'a, wprowadza inne rozumienie kompozycji między formą a substancją. „Przez formę należy więc rozumieć w sensie Hjemslevowskim pewien abstrakcyjny schemat albo pewną abstrakcyjną zasadę organizowania

30 Jak zauważa Julia Kristeva (1974), według Hjelmsleva 'struktura znaku mogłaby być pierwotnie analizowana przez niejęzykowe dyscypliny (fizykę albo antropologię), podczas gdy poprzez serię dedukcyjnych działań nauki językoznawcze mogłyby wytworzyć lingwistyczny schemat, który przejawiałby się przez lingwistyczne użycie' (Kristeva 1974: 235),

31 Tu należy zwrócić uwagę na pewną historiograficzną dialektykę. Związki między semiotyką Hjelmsleva a szkołą paryską (l'École [sémiotique] de Paris, zgrupowaną początkowo m.in. wokół Algirdasa Juliena Greimasa) stanowią z kolei temat dogłębnego opracowania autorstwa Alessandro Zinna (2017 inter alia). Autor uzasadnia w nim między innymi tezę, iż semiotyka szkoły paryskiej została przede wszystkim 'zakotwiczona na założeniach epistemologicznych i terminologicznych teorii Hjelmsleva' (Zinna 2017: 456). Co więcej zauważa on, że tradycja tej szkoły nie tylko zasadza się na zapożyczeniach ale nawet, co istotniejsze, na elementach odrzuconych czy wręcz zdradzonych ([fr.] „trahi”) z teorii Hjelmsleva (Zinna 2017: 462). Niemniej jednak, Zinna jednocześnie podkreśla, że 'w pewnym sensie trzeba zdradzić Hjelmsleva, aby zbudować teorię znaczenia (która, nie zapominajmy, jest teorią substancji, treści, według duńskiego autora), tak jak trzeba odejść od Greimasa, aby zbudować semiotyczną dynamikę praktyki wypowiedzi, [praktyki] kontinuum, poziomów istotności, percepcji i ciała. I oczywiście te zdrady stają się konieczne, a nawet niezbędne, dla dynamiki badań' (Zinna 2017: 457). 
relacji strukturalnych między funktywami powiązanymi ze sobą funkcją znakową w obydwu planach, w planie wyrażania i planie treści” (Wąsik 1997:40).

Teoria znaku Hjelmsleva współcześnie często pojawia się w opracowaniach semiotyków. Na przykład Miriam Taverniers (2008) rekonstruuje krok po kroku teorię znaku Hjelmsleva, według jej głównych wymiarów różnicujących. Podkreśla, że na podstawowym poziomie diada treść - wyrażenie może być porównywalna z terminami Saussure’a. Jednakże na bardziej abstrakcyjnym poziomie, 'jest to relacja, która powtarza się na różnych poziomach abstrakcji poprzez różne typy systemów semiotycznych, włączając w to język’ (Taverniers 2008: 370). Według tej badaczki, najistotniejszym wkładem Hjelmsleva w rozumienie semiozy jest samo jego ujęcie semiotyki zasadzającej się na wielowarstwowości znaku, rozwijane w ramach rozróżnienia między semiotyką denotatywną, konotatywną i metajezykową (Taverniers 2008: $370)$.

Teoria znaku Hjelmsleva prowadzi do teorii fonologii. Jak podkreśla Taverniers (2008: 385), Hjelmslev nazywa elementy wyróżnione w analizie form 'inwariantami', a te, do których dochodzi się w analizie substancji - 'wariantami'. Wprowadza też rozróżnienie między dwoma typami wariantów: wariancje ('variations') to inaczej 'dowolne' warianty, pojawiające się niezależnie od środowiska. Drugą kategorię nazywa 'odmianami' ('varieties') i określa tym mianem warianty związane, czyli pojawiające się tylko w danym środowisku innych elementów z którymi się łączą. Taverniers dalej zauważa, że Hjelmslev wyjaśnia warianty szeroko na płaszczyźnie wyrażenia, gdzie nadbudowuje na wcześniejszych pracach z fonetyki i fonologii, łącząc inwarianty najwyższego stopnia $\mathrm{w}$ płaszczyźnie wyrażania $\mathrm{z}$ fonologiczną kategorią fonemu (Taverniers 2008: 385). Obydwa typy wariantów są również wyjaśnione w terminach fonicznej strony języka: wolne warianty (wariancje/ zmiany) stanowią 'wszystkie możliwe specimeny dźwięku, które pojawią się jako odmienne w dostatecznie czułej eksperymentalnofonetycznej rejestracji' (Taverniers 2008: 385).

\section{Podobieństwo i przyleglość w semiotyce Romana Jakobsona}

Jakobson blisko współpracował $\mathrm{z}$ akademikami stowarzyszonymi w wielu różnych nurtach nauki i sztuki. Należy tu też nadmienić, że był on vice-przewodniczącym założonego przez Vilema Mathesiusa Praskiego Koła Lingwistycznego, współtworzonego m. in. przez Mikołaja Trubeckiego, Sergeja Karcevskiego, René Welleka i Jana Mukařovskiego ${ }^{32}$. Szczególnie w

32 Patrz szerzej na przykład Goldsmith i Laks (2016). 
swoich wcześniejszych pracach dotyczących semiotyki Jakobson podzielał saussure’ański pogląd na pierwszeństwo systemu semiotycznego nad językowym, określając systemy znaków jako idiomorficzne, przy czym

język pozostaje w centrum wszystkich ludzkich systemów semiotycznych, i jest wśród nich najważniejszy. Co za tym idzie, ,językoznawstwo jest głównym trybutarzem semiotyki”, jak to napisał Leonard Bloomfield. Z drugiej strony, każda konfrontacja języka ze strukturą innych systemów ma pierwszorzędne znaczenie dla językoznawstwa, ponieważ wykazuje (niektóre) właściwości wspólne dla znaków i innych systemów semiotycznych, i uwypukla specyficzne cechy języka.

$(\text { Jakobson 1973: 28) })^{33}$

Jednakże Jakobson nie wyprowadza fonocentryczności swoich teorii explicite od Saussure'a, ale cytuje tu językoznawców takich jak Edward Sapir ('język fonetyczny wyprzedza wszystkie inne typy symbolizmu komunikacyjnego') czy Émile Bienveniste, dla którego 'język jest wyrażeniem symbolicznym par excellence i wszystkie inne systemy komunikacji z niego wychodzą' (Jakobson 1973: 32) ) $^{34}$

W późniejszym okresie działalności naukowej Jakobson włączył w swoją teorię niektóre osiągniecia semiotyki Peirce’a ${ }^{35}$. Według Edwarda Stankiewicza (ucznia i współpracownika Jakobsona), kiedy Jakobson podjął ‘wytarty przez czas' motyw naturalnej czy arbitralnej natury znaku językowego, wskazał na częstą obecność znaku ikonicznego pośród zasadniczo symbolicznej natury języka. Jak dalej nadmienia Stankiewicz, takie teoretyczne volte face mogło powstać dlatego, że Jakobson nie utożsamiał znaczenia z referentem (denotatum), ale z signatum, które zakłada istnienie referenta będącego jednym $\mathrm{z}$ możliwych wariantów kontekstualnych (Stankiewicz 1983: 11). Odpowiedniość między signans i signatum zaistnieje więc tylko, gdy signans wywołuje diagramatycznie ogólne znaczenie signatum. Co więcej, Jakobsonowskie ujęcie ikoniczności kontrastuje z ogólnie przyjętym ze względu na swoją relatywność: według Jakobsona poszczególne języki mogą wyrażać te same kategorie w sposób

33 Pozycja adnotowana jako "Jakobson (1973)" jest w istocie francuskojęzycznym wydaniem wyboru artykułów, które Roman O. Jakobson pisał w latach 50. i 60. XX wieku.

${ }^{34}$ Teorię Jakobsona z pewnością należałoby przedstawić w jeszcze szerszym kontekście, nawet wspominając o jego fascynacji fenomenologią Husserla. Również teoria języka samego Karla Bühlera, a w szczególności pojęcie indeksacyjności, ze względu na ograniczenia długości artykułu, nie zostanie tu omówiona. Te wątki zostawiam jako otwarte do dalszych badań w przyszłości.

${ }^{35}$ Według Lindy Waugh i Monique Montiville-Bourston, 'myśli Jakobsona rozwijały się w przeciwstawieniu do idei Saussure'a, które Jakobson uważał za zbyt abstrakcyjne, dychotomiczne i uproszczone' (2002: XV). Dalej autorki podkreślają, że według Jakobsona nie należy rozdzielać pojęć langue i parole a zamiast tego, trzeba widzieć ich funkcjonalne i strukturalne powiązania: 'langue istnieje dla budowy instancji parole, a pomyślne działanie instancji parole zależy od langue' (Waugh, Montiville-Bourston 2002: XXII). 
ikoniczny lub symboliczny, podczas gdy 'sama ikoniczność ma naturę zmienną i właściwą dla danego języka formę' (Stankiewicz 1983: 11) ${ }^{36}$.

W wykładzie wygłoszonym w Erfurcie w 1959 r., który ukazał się w druku w 1985, Jakobson stwierdza wprost, że z całej ogromnej dyskusji nad arbitralnością czy ‘nieomotywaniem' znaku można wywnioskować, że arbitraire ${ }^{37}$ to zupełnie niefortunny termin naukowy. Dalej badacz przywołuje dokonana Kruszewskiego (jak podkreśla, ‘współczesnego Saussure'owi i bardzo przez niego szanowanego'), który jeszcze w latach 80. XIX wieku podszedł do zagadnienia w zupełnie inny sposób, a mianowicie robiąc rozróżnienie pomiędzy dwoma podstawowymi czynnikami w danym okresie trwania języka, dwoma rodzajami asocjacji: podobieństwa i przyległości (wziętymi z logiki Johna Stuarta Milla, 1806-1873, patrz sekcja 2). Z tej perspektywy,

relacja między signans i signatum, którą Saussure arbitralnie opisał jako arbitralną, jest w rzeczywistości zwyczajową wyuczoną przyległością (contiguity), obowiązkową dla wszystkich członków danej społeczności. Ale, wraz z tą przyległością, narzuca się zasada podobieństwa - la ressemblance. Mam wrażenie, że drugą zasadę w Saussure'owskim Kursie, tak zwaną linéarité, również trzeba traktować jako niebezpieczne uproszczenie. W praktyce napotykamy więc dwie jednostki wymiarowe nie tylko na poziomie signatum jak to wykazał $\mathrm{Ch}$ [arles] Bally, ale też w polu signans. Jeśli przyznamy, że fonem nie jest ostateczną jednostką języka, ale może być rozłożony na cechy dystynktywne, wtedy staje się oczywiste, że w fonologii możemy również mówić o wymiarach (w sposób, jaki mamy np. akordy w muzyce) - wymiarach następowania i jednoczesności.

(Jakobson 1985: 28-29)

Kolejny podział sugerowany przez Jakobsona to rozróżnienie między homogenicznymi przekazami (czyli takimi, które korzystają tylko z jednego systemu semiotycznego), a przekazami synkretycznymi, stosującymi kombinację czy fuzję różnych systemów semiotycznych. Wizualne znaki cielesne wykazują tendencję łączenia się z systemami znaków

\footnotetext{
${ }^{36}$ We wprowadzeniu do opublikowanych wykładów wygłoszonych przez Jakobsona w New York École Libre des Hautes Études w latach 1942-43 Claude Lévi-Strauss nadmienia, iż 'w szóstym wykładzie Jakobson zabiera [czytelnika] ponad zasadę arbitralności znaku. Znak oczywiście, wydaje się arbitralny, gdy na niego patrzymy z punktu widzenia podobieństwa, to znaczy, kiedy porównujemy różne elementy znaczące tego samego elementu znaczonego (signified) w różnych językach, ale jak wykazał Bienveniste, znak nie wydaje się arbitralny dla każdego języka rozważanego oddzielnie, gdy popatrzymy na niego z punktu widzenia przyległości, biorąc ją jako konieczną relację między znaczącym a znaczonym. W poprzednim wypadku relacja jest wewnętrzna, w ostatnim zewnętrzna' (Lévi-Strauss 1978: XVII).

${ }^{37}$ Zob. też uprzednio cytowaną pracę Kima, gdzie widzimy, że takie same problemy z określeniem 'arbitralny' miał już sam de Saussure.
} 
audytywnych. Na przykład, gesty dłoni i wyrazy twarzy funkcjonują jako znaki, dodając do wypowiedzi werbalnej jako ich zamienniki, podczas gdy poruszenia wprawiające w ruch kończyny i całe ciało wydają się być bardziej związane z muzyką instrumentalną (Jakobson 1973: 101). Wiesław Awedyk (1975) zauważa, że to podejście Jakobsona było krytykowane m. in. przez Polivanova i Bühlera, którzy, tak jak de Courtyenay, widzieli korelacje między produkcją a percepcją mowy. Na przykład Bühler podkreślał, że kiedy podejmujemy się czynności słuchania, nie stajemy się tylko akustycznymi odbiornikami, a z kolei kiedy zaczynamy się wypowiadać, również nie zamieniamy się w głuche nadajniki. Bardziej odpowiednie będzie zatem określenie wewnętrznej rejestracji i kształcenia własnych programów pod kontrolą słuchających uszu (Bühler 1934: 268; cyt. za: Awedyk 1975: 40) ${ }^{38}$.

W ramach wkładu Jakobsona w rozwój semiotyki można wspomnieć jeszcze o kategorii sygnałów, którą ten językoznawca proponuje oddzielić od innych systemów semiotycznych: sygnał, tak jak jakikolwiek inny typ znaku, przenosi swój signatum, ale w odróżnieniu od innych znaków, sygnały nie mogą się łączyć w nowy semiotyczny konstrukt, nawet, jeśli same należą do kodu większych jednostek wybranych ad libertum. Mogą być one zarówno czasowe jak i przestrzenne, audytywne jak i wizualne. Co więcej, jeśli system posiada nie tylko sygnały proste, ale też złożone, wszystkie kombinacje sygnałów prostych są określone przed kod, w wyniku czego powstały zbiór możliwych przekazów staje się ekwiwalentem kodu. Zostają one przypisane albo do indeksu ikon albo do indeksu symboli przez semiozę sygnału (Jakobson 1973: 101).

\section{Semiotyczne parametry $w$ badaniach językoznawczych Wolfganga $U$. Dresslera}

Językoznawcą, który współcześnie nobilitował semiotykę do statusu metateorii językoznawstwa był Wolfgang U. Dressler. Semiotyczny wkład Dresslera do fonologii doczekał się wielu opracowań (patrz na przykład Dziubalska-Kołaczyk 2002; Pociechina 2009). Nie

38 „Wir sind, wenn wir hörend aufnehmen, mehr und ganz anderes als rein akustische Rrezeptoren; und wenn wir selbst sprechen, sind wir mehr und anderes als taube Sender. Sondern wir nehmen das Gehörte innerlich mitkonstruierend (oft förmlich nachsprechend) auf und erzugen die eigenen Sendungen unter der wirksamen Kontrolle unseres mithörenden Ohres" (Bühler 1934: 268; cyt za: Awedyk 1975: 40). Sam de Courtenay, jak dalej pisze Awedyk, „wprowadził dwa terminy: kinemę (wysiłek artykulacyjny) i akusmę odpowiadający mu efekt akustyczny), (...) które zdefiniował jako 'nierozdzielną, ale Janusową całość, z jedną twarzą patrzącą w kierunku strony fizjologiczności (artykulacji) a drugą, patrzącą w kierunku aspektu akustycznego' (Baudouin de Courtenay 1922: 22). Fonem był dla niego dwutwarzowym elementem, składającym się z psychologicznego przedstawienia ruchów artykulacyjnych i równoważnych psychologicznych przedstawień efektów słuchowych" (Awedyk 1975: 40). Zob. też: Ruszkiewicz (1973). 
stosuje się zatem do niego ogólne kryterium walencyjne niniejszego tekstu (mniej znane badania znanych badaczy lub prace mniej znanych ('non-mainstream') badaczy). Jednakże ze względu na ogromny udział, jaki semiotyka ma w oeuvre tego naukowca, nie sposób go po prostu pominąć mówiąc o synergii epistemologicznej językoznawczo-semiotycznej. Chciałabym zatem przedstawić i omówić wyimek z jego myśli - zastosowanie semiotyki do badań morfopragmatycznych i aspekty interakcji kryterium ikoniczności $\mathrm{z}$ innymi semiotycznymi parametrami ${ }^{39}$.

Jak stwierdzają Dressler i Barbaresi, proces komunikacyjny można postrzegać semiotycznie. Ponadto tekst, a w szczególności jakakolwiek morfo-pragmatycznie istotna reguła w tym tekście (jako podstawowa jednostka tego procesu), może być ujmowana jako znak (Dressler i Barbaresi 1994: 8). Badacze motywują wybór semiotyki peirce’ańskiej nad saussure'ańską, stwierdzając, że ta pierwsza wydaje się bardziej odpowiednia do podejścia dyskursywnego. Według tych autorów, zamiast redukować znak do statycznej relacji między signans i signatum jak to zrobił Saussure, Peirce podkreśla wagę interpretatora w dynamice semiozy. Słowa Peirce’a 'nic nie jest znakiem, dopóki nie jest intepretowane jako znak', nie wskazują zatem na potencjalność relacji między signans i signatum, ale odnoszą się do faktycznej sygnifikacji jakiegokolwiek przykładu (kognitywnego czy komunikatywnego) semiozy, co jest poziomem pragmatyki (Dressler, Barbaresi 1994: 8 i nast.).

Specyficznym zagadnieniem $\mathrm{w}$ tak pojętej perspektywie jest zastosowanie pojęcia indeksu do analiz morfo-pragmatycznych. Wychodząc z uprzednio przedstawionej definicji Peirce'a, Dressler i Barbaresi zauważają, że indeksacyjność może wskazywać na jakiś element albo w kontekście sytuacji (deiksa egzoforyczna), albo na element kontekstualny; to znaczy, w obrębie samego tekstu (deiksa endoforyczna). Tu z kolei rysują się dwie możliwości: albo w kierunku cofającym się (anafora) albo postępującym (katafora) (Dressler, Barbaresi 1994: 9). W swoich publikach na temat morfologii naturalnej Dressler wskazuje, że naturalność nie odnosi się do jakiejkolwiek całościowej preferencji, ale raczej to tego, co jest uniwersalnie preferowane $\mathrm{w}$ odniesieniu do danego parametru. Z kolei parametry i ich odpowiednie preferencje można wydedukować z czynników semiotycznych i kognitywnych.

Oczywiście, niniejszy zakres tematyczny nie pozwala na wchodzenie w polemikę z tymi poglądami, zatem ograniczę się tylko w tym miejscu do stwierdzenia, że nawet w wyszczególnieniach myśli Saussure’a w tym opracowaniu, zarówno z Kursu, jak i Szkiców, nic

${ }^{39}$ W pracy Haładewicz-Grzelak (2018: 95-98) analizuję podejście Dresslera do kategorii semiotycznych w wymiarze językoznawstwa naturalnego. 
nie zaprzecza stwierdzeniu, że „nic nie jest znakiem dopóki nie jest intepretowane jako znak”, natomiast Saussure, moim zdaniem słusznie, kładzie nacisk na społeczną i kulturalną wartość znaku językowego - czyli w pewnym sensie bardziej wymierną analitycznie - raczej niż na indywidualną interpretację. Mamy tu więc do czynienia z dwoma rozłącznymi horyzontami analitycznymi: introspekcji i badania znaku jako takiego, lub badania relacji jednego znaku do innych $^{40}$. Każda z tych metod umożliwia uzyskanie innych wniosków analitycznych, i żadna nie może być inherentnie uznana za lepszą czy gorszą od drugiej.

Paradygmat językoznawstwa naturalnego w wersji rozwijanej przez Dresslera nie zakłada istnienia osobnego modułu gramatycznego, ale próbuje wyszczególnić czynniki kognitywne i poza językowe (włączając w to semiotykę jako zestaw parametrów, Dressler 1995: 22). Niektóre z parametrów semiotycznej wyrazistości zaproponowanych przez Dresslera przedstawiają następująco:

1. Parametr ikoniczności, który zakłada, że dla morfologii, morfosemantycznie naznaczona kategoria, w porównaniu do nienaznaczonej kategorii, jest wyrażona przeważnie przez dłuższą formę. Wyjaśnia on również, dlaczego działania indeksacyjne są preferowane wobec nie indeksacyjnych.

2. Parametr morfotaktycznej przeźroczystości ${ }^{41}$.

3. Parametr morfosemantycznej przeźroczystości: pełna przezroczystość oznacza znaczenie w pełni kompozycyjne, jak to ma miejsce z większością końcówek fleksyjnych.

4. Parametr optymalnego kształtu: optymalny kształt leksemu to rozszerzenie [powielanie] stopy metrycznej, z którego to powodu preferowane są słowa dwusylabowe, a optymalnym kształtem afiksu jest jedna sylaba.

40 W Szkicach z językoznawstwa ogólnego (Saussure [2004]), w niezaprzeczalnie autentycznych słowach Saussure'a, czytamy na przykład: „Żaden język lub system semiotyczny nie jest okrętem w budowie, ale okrętem na pełnym morzu. Od chwili, gdy dotknął wody, daremnym byłoby sądzić, że można prześledzić jego kurs, nawet, jeśli się zna dokładnie jego szkielet, jego wewnętrzną, zgodną z planem, konstrukcję (...). Tylko ten system znaków, który stał się faktem społecznym, rzeczywiście zasługuje na miano systemu znaków, ponieważ od tego momentu ogół warunków jego funkcjonowania odróżnia go od wszystkiego, czym mógłby być niezalenie od tego, że owa reszta okazuje się całkiem nieistotna (...). Dotarłszy do tego punktu można zauważyć, jak horyzont semiotyczny się zawęża i klaruje, wszystkiemu bowiem, co jest podobne do znaku, odmawiamy natury, która za swoją podstawę miałaby warunki indywidualne - albo, dokładniej rzecz ujmując, za semiologiczną uznajemy tylko tę część zjawisk, które w bardzo charakterystyczny sposób jawią się jako wytwór społeczny" (Saussure 2004: 266267).

41 Thomas Berg objaśnia parametr przeźroczystości w następujący sposób: ‘[parametr], w którym signans i signatum wchodzą w maksymalnie bezpośrednią relację, czyli relację, która jest minimalnie zniekształcona przez ingerujące zmienne. Ta zasada przewiduje, że relacje morfologiczne są posłuszne uwarunkowaniu przezroczystości. Im bardziej przeźroczysta jest dana relacja morfologiczna, tym częściej wystąpi w językach świata' (Berg 1998: 37). 
5. Parametr binarności: binarne relacje morfologiczne są preferowane wobec ternarnych czy n-arnych (Dressler 1995, 1999, 2005, 2009 inter alia).

$\mathrm{Z}$ tego zestawu jednym z ważniejszych jest niezaprzeczalnie parametr ikoniczności, stanowiąc główną podstawę do teorii znaku. Jak podkreśla austriacki językoznawca:

[i]koniczność zawsze odnosi się do podobieństwa między signans i signatum w umyśle osoby intepretującej (która tworzy interpretanta). Signifiant i signifié są tylko jednym rodzajem signans i signatum, ponieważ również fonem może być signatum, a jego alofony mogą być odpowiednimi signantia lub też znak językowy może być signans dla jakości kognitywnej (np. pojęcia), jako jego signatum.

(Dressler 1995: 22)

Powyższe parametry tworzą specyficzną analityczną siatkę, wchodząc ze sobą w zbieżne interakcje („,convergent interactions”). Na przykład różne typy reduplikacji w dyskursie wyjaśnione są współgraniem niektórych parametrów - połączeniem ikoniczności z indeksacyjnością. Możliwe są również interakcje $z$ diagramatycznościa i semantyczną przezroczystością, czy też zasadą figury i tła (Dressler 1995: 25). Ikoniczność zatem w tej analizie jawi się jako pewien istotny czynnik regulacyjny.

Parametry mogą też wchodzić ze sobą w konflikt. Dressler proponuje następującą ogólną klasyfikację konfliktów: pierwsza kategoria: konflikt ikoniczności z innym parametrem versus konflikt między sub-parametrami samej ikoniczności. Druga kategoria: konflikt mający miejsce w ramach tego samego komponentu (na przykład morfologii, fonologii) versus konflikt pomiędzy różnymi komponentami. Na przykład, relatywna sporadyczność egzocentrycznych złożeń wynika $\mathrm{z}$ konfliktu ikoniczności $\mathrm{z}$ innym parametrem $\mathrm{w}$ ramach tego samego komponentu. W endocentrycznych złożeniach powstaje diagramatyczność pomiędzy morfosemantycznym a morfotaktycznym członem nadrzędnym (np. corner stone / stone corner) (Dressler 1995: 30).

Konflikt między diagramatycznością a ekonomią tekstualną widoczny jest również na przykładzie elipsy:

Ponieważ indeksacyjność anaforyczna jest łatwiejsza do ustalenia, jeśli indeksacyjny signans odnosi się do figury niż [gdy odnosi się] do tła, łatwiej jest odnieść się anaforycznie i eliptycznie do bohatera niż do nie-bohatera powieści. Ponadto, anaforyczne odniesienie poprzeczne do elementu poprzedzającego wspomnianego wcześniej jest bardziej efektywne, a przez to bardziej naturalne, niż kataforyczne odniesienie do następującego elementu [...], 
tj. ko-referencyjny poprzednik jest łatwiejszy do odzyskania niż ko-referencyjny następnik.

W rezultacie elipsa anaforyczna jest znacznie bardziej rozpowszechniona niż elipsa kataforyczna.

(Dressler 1995: 31$)^{42}$

Na tych wyrywkowych przykładach widzimy, że austriacki językoznawca identyfikuje pewne regulacyjne czynniki, jednakowe dla interpretacji zjawisk dotyczących modułu fonologii, morfologii czy retoryki (poziomu większych jednostek tekstowych). Kluczowym odniesieniem w tych wyjaśnieniach jest semiotyka w wersji zaproponowanej przez Charlesa Sandersa Peirce'a.

\section{Fenotekst i genotekst w semiotycznym polu pulsacji znaczenia Julii Kristevy}

Semiotyczne językoznawstwo kontrowersyjnej postaci $\mathrm{z}$ historii rozwoju teorii dyskursu $\mathrm{z}$ punktu widzenia semiotyki - Julii Kristevy, określanej często mianem badaczki poststrukturalistycznej, ale też post-modernistycznej (w zaangażowanym politycznie i społecznie nurcie swojego pisarstwa), pozostaje na ogół w cieniu bardziej utytułowanych kolegów po fachu (np. Rolanda Barthesa, czy Algirdasa Greimasa). Z jednej strony, ogólny zarys teorii tej myślicielki odchodzi od metodologicznego zakresu niniejszych badań, z drugiej, ponieważ Kristeva sama jest autorką bardzo wielu opracowań językoznawczo-semiotycznych (np. Kristeva 1969, 1980), warto pokrótce naszkicować główne założenia jej teorii poświęcone relacjom semiotyki z językoznawstwem ${ }^{43}$.

Na początku swojej działalności naukowej Kristeva stowarzyszona była w Paryskim Kole Semiotycznym (Le Cercle de Sémiotique de Paris, powstałym w 1969), w znamienitym towarzystwie m. in. Emila Benveniste'a jako przewodniczącego, tudzież Claude'a Lévi-

42 ,Since anaphorical indexicality is easier to establish if the indexical signanas refers to a figure than to the ground, it is easier to refer anaphorically and elliptically to the hero than to the non-hero of a story, Next, on the parameter of indexicality, anaphoric cross reference to an antecedent mentioned before is more efficient and thus more natural than cataphoric cross-reference to a later coming postcedent [...] i.e. a coreferent antecedent is easier to recover than coreferent postcedent. As a result, anaphoric ellipsis is much more widespread than cataphoric ellipsis" (Dressler 1995: 31).

${ }^{43}$ Kristeva jest też autorką tak dzisiaj modnego pojęcia 'intertekstualnośći', które zresztą następnie owocnie rozwijał jej bliski współpracownik, Roland Barthes. Zajmowała się również fenomenologią nowoczesnego (ówcześnie) językoznawstwa, w pracy „Les épistemologies de la linguistique”, w: Languages No 24. 1971. 11. Nurt jej fascynacji Freudem i podświadomością pominę w niniejszej prezentacji, jako znacznie wykraczający poza główną myśl tematyczną artykułu. 
Straussa, Christiana Metza, François Rastiera, Algirdasa Greimasa czy Tzvetana Todorova ${ }^{44}$. W swojej teorii semiotycznej, pozostającej w opozycji do Kursu Saussure'a, Kristeva (1974) rozróżnia dwie modalności procesu znaczeniowego: w moim thumaczeniu pierwsza semiotyczność (le sémiotique) a druga - symboliczność (le symbolique) (Kristeva 1974: 22). Jak stwierdza dalej ta myślicielka, są one nierozdzielne w procesie signifikacji konstytuującym język. Poszczególne typy dyskursu (na przykład metajęzyk, poezja czy narracja) zdefiniowane są poprzez dialektykę tych modalności, dlatego też język, który określamy jako 'naturalny' może tolerować różne sposoby artykulacji symboliczności i semiotyczności. Ponieważ każdy podmiot jest zawsze jednocześnie symboliczny i semiotyczny, nie mogą istnieć systemy znaczeniowe 'wyłącznie' semiotyczne czy 'tylko' symboliczne, ale podmiot 'zawsze jest naznaczony długiem jednego względem drugiego' (Kristeva 1974: 22).

Kristeva zapożycza od Platona termin chora (Khora / Chora; starogrecki: $\chi \omega ́ \rho \alpha$, rodzaj tańczącego ciała) do oznaczenia prowizorycznej artykulacji, mobilnej i konstytuowanej przez poruszenia (mouvements) i ich efemeryczne wierzchołki (stasis). Odróżnia tę niezdeterminowaną artykulację od dyspozycji

która już jest częścią znaczenia i do której stosuje się przestrzenna intuicja fenomenologiczna, aby dać miejsce geometrii (...). Zanim jeszcze się stanie pozycją, która przedstawia coś dla kogoś, to znaczy, zanim jeszcze zostanie znakiem, chora nie jest już pozycją, która reprezentuje kogoś dla innej pozycji, to znaczy ona nie jest jeszcze signifiant, ale ona tworzy się wobec takiej znaczącej pozycji (...). Teoria podmiotu zaproponowana przez teorie nieświadomości pozwoli nam odczytać $\mathrm{w}$ tej zrytmizowanej przestrzeni, bez tezy, bez pozycji, proces konstytuowania się znaczenia. Platon nas tam wprowadza sam, ponieważ określa to naczynie jako żywicielskie i maternistyczne, jeszcze nie zjednoczone w Uniwersum, ponieważ Bóg jest tam nieobecny.

(Kristeva 1974: $24-25)^{45}$

Ta filozoficzna ścieżka prowadzi Kristevę do funkcji semiotycznych pré-øedipiennes, 'wyładowań energii, które łączą i orientują ciało w odniesieniu do matki' (Kristeva 1974: 26):

${ }^{44}$ Informacja za artykułem: [brak autora] „Le cercle de sémiotique de Paris”. Semiotica, 4(3); 286-294.

45 Ponieważ styl pisania Kristevy jest co najmniej hermetyczny i idiosynkratyczny, co generuje wątpliwości przy próbie tłumaczenia, przytaczam poniżej ten urywek w wersji oryginalnej: „Sans être encore une position qui représente quelque chose pour quelqu'un, c'est à-dire, sans être une signe, la chora n'est plus une position, qui représente quelqu'un pour une autre position, c'est-a-dire, qu'elle n'est pas encore une signifiant; mais elle s'engendre en vue de telle position signifiante (...). Il faudra redonner à cette modalité son jeu gestuel et vocalique (...). La théorie du sujet proposée par la théorie de l'inconscient nous permettra de lire dans cette espace rythmé, sans thèse, sans position, le procès de constitution de la signifiance. Platon nous y introduit lui-même, lorsqu'il désigne cet réceptacle comme nourricier et maternel, non-encore unifié en Univers, car Dieu en est absent" (Kristeva 1974: 23-24). 
freudowskie tereny, na które nie będziemy się już głębiej zapuszczać. Warto nie mniej jednak zauważyć, że dla Kristevy językoznawstwo powinno przedsięwziąć badanie podmiotu wielowalencyjnego, który pozostanie na przednim planie semiologii, ponieważ to pojęcie jest nierozerwalnie związane $\mathrm{z}$ teorią podmiotu biorącą pod uwagę Freudowską teorię podświadomości (1974: 30). Jak zauważa Carrière (2002: 194), 'semiotyczna chora oznaczona w praktykach znaczących funkcjonuje tylko wewnątrz symboliczności. W ten sposób, semiotyczność warunkuje symboliczność'. Zatem to, co Kristeva rozumie poprzez znaczenie, stanowi 'ciągłe funkcjonowanie pulsacji, w kierunku, wewnątrz i poprzez język - jest to heterogeniczny proces, a nie struktura, jak utrzymywałaby fenomenologia' (Carrière (2002: 194).

Kristeva proponuje dwa terminy na określenie procesu znaczenia: fenotekst (le phénotexte) i genotekst (le génotexte). 'Fenotext' (phéno - tu ucięta forma od rzeczownika (fr.) phénomène, to składowa, która podkreśla aspekt przejawiania się tekstu jako fenomenu zawarty w tym terminie $^{46}$. Genotekst składałby się z przestrzeni przed-językowej (pré-linguistique) i przedpodmiotowej (pré-subjectif), dostarczając warunki nieznaczące znaczenia (Kristeva 1974: 14). Genotekst oznacza proces przekraczający struktury komunikatywne, który przestawia granice społeczne zainstalowanych praktyk społecznych - jak dalej podkreśla Carrière, jest to jedyna u Kristevy więź między językową a społeczną rewolucją. Tak jak poprzednio wspomniane pojęcia „symboliczność” i „semiotyczność”, współgrają ze sobą, w każdym procesie znaczenia genotekst współdziała z fenotekstem (Carrière 2002: 194).

\section{Synergia pojęć językoznawczych Yishaia Tobina}

W ostatniej części niniejszego wywodu chciałabym pokrótce pokazać, w jaki sposób jeden z wielkich propagatorów paradygmatu fonologii jako ludzkiego zachowania (Phonology as Human Behavior) - fonolog, psycholingwistyk i znawca izraelskiego języka migowego, Yishai Tobin, zastosował semiotykę jako metodę badań językoznawczych. Za najważniejszą pracę Tobina zajmującą się związkami językoznawstwa i semiotyki niewątpliwie należy uznać Semiotics and Linguistics, wydaną w 1990. We wstępie badacz nadmienia między innymi, że językoznawcy powinni dowiadywać się jak najwięcej o alternatywnych podejściach do analiz

46 Według definicji stownika la Langue française [por.

https://www.lalanguefrancaise.com/dictionnaire/definition/phenotexte. Data ostatniego dostępu: 30-01-2021] „phénotexte, phéno-texte , subst. masc., ling. (sémiologie). „L'aspect sous lequel le texte se présente, la formule de la signifiance dans la langue naturelle" (Recherches pour une sémanalyse, 1969, p.286 ds Sémiotique: I'École de Paris, Paris, Classique Hachette, 1982, p.146). 
językowych, choćby tylko po to, aby móc docenić różnice (Tobin 1990: XII). Wychodząc z tego założenia, głównym celem pracy Tobina jest właśnie podkreślenie powiązań między tymi dwiema dziedzinami wobec współczesnych tendencji do rozdzielania i kierowania ich w różne strony badawcze. W szczególności, badacz stwierdza, że jego praca pragnie ukazać możliwości, które mogłyby powstać, jeślibyśmy w językoznawstwie poważnie podeszli do nakierowania badań na znak (Tobin 1990: 17).

W tym duchu językoznawca ten definiuje język jako 'system systemów (układających się wokół pojęcia znaku językowego), wewnętrznie zorganizowanych, systematycznie powiązanych i używanych przez istoty ludzkie do komunikowania się' (Tobin 1990: 47). Takie semiotyczne podejście, jak podkreśla dalej Tobin, explicite zakłada poleganie na konkretnych danych badawczych, wyekscerpowanych zarówno z dyskursu mówionego jak i pisanego, biorąc pod uwagę też dane introspektywne i różne językoznawcze i sytuacyjne konteksty. Co więcej, tak pojęta perspektywa zakłada zajęcie się czynnikiem ludzkim, rozumianym jako całość kognitywnych, językowych, perceptualnych jak też i niejęzykowych zachowań istot ludzkich, ‘jako że ma ona odniesienie do postulowania niezmiennych znaczeń i wynikającej komunikacji specyficznych przekazów w dyskursie' (Tobin 1990: 47-48). Definicja ta, według samego badacza, obrazuje ‘podstawowy, europejski strukturalistyczny pogląd na język' i można ją ująć schematem podanym poniżej w Ryc. 1.
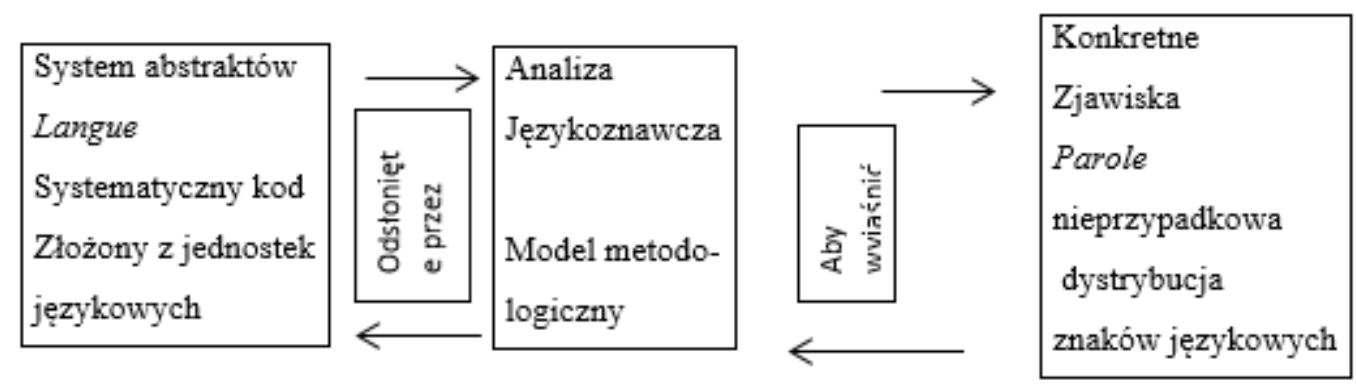

Ryc. 1. Strukturalny model języka, zaadaptowany z Tobina (1990: 48).

Model ten, według Tobina, łączy się z większym, całościowym konceptem synerezy, jako fundamentalnym pojęciem leżącym u podstaw całego języka. Synerezę językoznawca ten rozumie jako takie wspólne działanie, w wyniku którego całość złożona z poszczególnych elementów przewyższa sumę tychże elementów branych z osobna (Tobin 1990: 48). Badając konkretne przekazy językowe, Tobin stwierdza m.in., że ujmując rzecz synergicznie, 'istnieje kooperatywna symbiotyczna relacja między czynnikiem komunikacyjnym a czynnikiem ludzkim w sposób zdefiniowany przez semiotyczny, czy zorientowany na znak pogląd na język' (Tobin 1990: 58). Praktyczna część badań Tobina składa się z dyskusji nad kluczowymi 
punktami semiotycznego podejścia do języka właśnie z punktu widzenia synergii, na przykład zakodowanie a odkodowywanie (czyli nadawca a obiorca przekazu); niezmienność (invariance) a wariancja (czyli znaczenie niezmienne versus znaczenie w dyskursie), aż po pojęcie gramatyki wobec leksykonu ${ }^{47}$.

Reasumując badania semiotyczne Tobina, należy podkreślić, że wychodząc od klasycznej, rozwiniętej przez Saussure'a definicji znaku językowego, w odróżnieniu od wielu badaczy dyskursu, nie tylko nie zaprzeczył zasadności klasycznego modelu, ale rozwinął go w taki sposób, że powstał paradygmat mogący objąć szerokie spektrum zachowania ludzkiego.

\section{Wnioski}

Przedmiotem zainteresowania badawczego w niniejszym artykule był zakres wybranych metod badawczych i podejść opracowywanych w ramach dziedziny określanej jako semiotyka, rozważanych z perspektywy językoznawczej. W szczególności skupiłam się na badaniach dotyczących znaku językowego i wkładzie językoznawców w tworzenie jego koncepcji teoretycznej. Za Katarzyną Dziubalską-Kołaczyk zaproponowałam 'osobiste spojrzenie' na poruszane zagadnienia, które polegało w tym wypadku, z jednej strony, na zagłębieniu się w mniej znane aspekty działalności wielkich językoznawców, a z drugiej, na omówieniu podejść językoznawczych pozostających poza głównym nurtem akademickim.

Synergię epistemologiczną wykazałam na wielu poziomach. Przede wszystkim należy zwrócić uwagę na nierozerwalny związek między semiotyką znaku a semiotyką znaku językowego, związek szczególnie widoczny w fonologii (prace Saussure'a, Dresslera, Jakobsona). Semiotyka już w początkach XIX wieku wniosła do językoznawstwa szerokie spojrzenie na system znakowości ludzkiej i warto o tym pamiętać, szczególnie kiedy obecnie nowsze modele mają tendencję kontrastowania swoich dokonań z rzekomo wąskim, ograniczonym i mechanistycznym poglądem na język ich poprzedników.

Po drugie, rozszerzając otwierające motto Katarzyny Dziubalskiej-Kołaczyk o „świeżość inności” Jerzego Bańczerowskiego, inna perspektywa na zjawiska językowe często uznane za oczywiste, czyli w tym wypadku, poprzez otwarcie pola do dyskusji, może przyczynić się do pogłębienia i umocnienia stanowisk epistemicznych, szczególnie biorąc pod uwagę fakt, że

47 To samo założenie metodologiczne i ten sam semiotyczny pogląd na język w połączeniu z teorią fonologii jako ludzkiego zachowania Wiliama Divera stanowi punkt wyjścia do badań izraelskiego języka migowego i porównania go z językiem mówionym (Tobin 2008). 
kolejne pokolenia coraz bardziej zawężają i pozbawiają kontekstu dokonania swoich poprzedników.

Zestawienie dokonań wybranych myślicieli i badaczy działających na styku językoznawstwa i semiotyki, zaproponowane w artykule, choć nie może być wyczerpujące, unaocznia wielowarstwowość zjawiska znaku językowego jako wyniku wielopoziomowej synergii. Z jednej strony, widzimy, że foniczna i graficzna/wizualna (materialna, patrz języki migowe) strona znaku, pozostaje poza immanentnością opozycji ${ }^{48}$, ale też teoria znaku umiejscawiana jest w szerokiej płaszczyźnie zachowania ludzkiego (Morris czy Tobin), a nawet warstw podświadomości przed-podmiotowej (Kristeva).

Językoznawcy przedstawieni $\mathrm{W}$ powyższej prezentacji wpisują się zarówno w dychotomiczny (ale synkretyzujący) wymiar prac (Saussure), jak i w triadyczny aspekt znaku, zakładający odniesienie do interpretanta (Dressler, Morris). Każda z obranych perspektyw semiotycznych - czy diadyczna czy triadyczna - znacznie pogłębia myśl językoznawczą. Szczególnie z badań Wolfganga Dresslera wyłania się ikoniczność jako pewna nadrzędna kategoria poznawcza, która, choć cytowana u austriackiego naukowca za Peirce'em, znacznie wykracza poza kategorie typu secondness. Znak językowy synergicznie odnosi się do, i uzupełnia zarówno poziom fonologiczny, morfologiczny, jak też pragmatyczny opisu językoznawczego.

Synergiczną retrospektywę wybranych zagadnień dotyczących znaku językowego chciałabym zakończyć cytatem z wielkiego językoznawcy André Martineta, który w roku 1968 w artykule zatytułowanym „Mot et synthème” ('Słowo i syntem’), napisał co następuje:

Najnowsza historia językoznawstwa pokazuje nam, że podejścia, które mogą wydawać się diametralnie przeciwne, w rzeczywistości odzwierciedlają tylko różną optykę, swoiste sposoby patrzenia i rozwiązywania problemów, przy czym nacisk kładziony jest w jednych na wypowiedź, a w innych, na paradygmat, problemy semantyczne są w jednej optyce czasowo przemilczane, w drugiej zaś, przeciwnie, znajdują się w centrum zainteresowania badawczego; jednakowoż zasadniczo nie ma sprzeczności w wynikach uzyskanych przy obu podejściach (...). Obie

48 Można przytoczyć tu też cytat z wykładów Saussure’a z 11 maja 1911, zanotowany przez jego studentów a opublikowany w pracy Bouissaca (2010: 22): ‘Pamiętajmy, że zarówno obraz akustyczny, jak i pojęcie są związane z podmiotem [podkreślenie moje, M.H.-G.]. Oba są mentalne. Obraz akustyczny nie jest dźwiękiem fizycznym, ale, że tak powiem, jego psychologicznym piętnem. Musimy oderwać się od naiwnego poglądu, że przedmioty i dźwięki są zestawiane, tak, że przedmioty znajdują się na zewnątrz podmiotu a rzeczowniki, które są nieco na zewnątrz jako zjawiska fizyczne, ale także wewnątrz jako zjawiska mentalne. Z tego punktu widzenia sytuacja nie jest jasna. Jeśli podchodzimy do problemu racjonalnie, oczywiste jest, że dwa terminy, to znaczy obraz akustyczny i koncepcja, uobecnione są w podmiocie. Wyraźnie dzieje się tak, jeśli pomyślimy o naszej mowie wewnętrznej, kiedy dźwięki słów pozostają w naszych głowach'. 
perspektywy są uzasadnione. Każdy kontynuuje swoje badania zgodnie ze swoim temperamentem i wykształceniem, i w ten sposób ostatecznie oświetlone są wszystkie oblicza [badanego] obiektu.

(Martinet 1968: 294)

\section{Bibliografia}

Awedyk, Wiesław (2007) „Zabrocki on Sound Change: Discussion”. (referat wygłoszony na międzynarodowej konferencji 38 Poznań Linguistic Meeting, 13-16 września, Gniezno).

Bańczerowski, Jerzy (2004) „Prądy aksjomatyzacyjne w językoznawstwie”. Scripta Neophilologica Posnaniensia 6; 15-72.

Beaugrande, de Robert, Wolfgang U. Dressler ([1981] 1990) Wstęp do lingwistyki tekstu.

[Einfuhrung in die Textlinguistik]. (tłum.) Aleksander Szwedek. Warszawa: Państwowy Instytut Wydawniczy.

Berg, Thomas (1998) Linguistic Structure and Change. Explanation from Language Processing.

Oxford: Clarendon Press.

Bühler, Karl ([1934/1999] 2004) Teoria języka. [Sprachtheorie: Die Darstellungsfunktion der Sprache] (tłum.) Jan Koźbiał. Kraków: Universitas.

Bühler, Karl (1934) Sprachtheorie. Die Darstellungsfunktion der Sprache. Jena: G. Fischer.

Bouissac, Paul (2010) De Saussure: A Guide for the Perplexed. London: Continuum Int. Publishing Group.

Carnap, Rudolf (1942) Introduction to Semantics and Formalization of Logic. Cambridge Massachusetts: Harvard University Press.

Chidichimo, Alessandro (2016) „Variantes Saussuriennes: écriture, recherche, style dans les manuscrits de Ferdinand de Saussure”. [W:] Michel Arrivé, Estanislao Sofia (red.) Le Cours de linguistique générale 100 ans après. Recherches Sémiotiques 24 (1-2-3); 113-136.

Chruszczewski, Piotr (2011) Językoznawstwo antropologiczne. Zadania i metody. Wrocław: Wydawnictwo PAN.

Chrzanowska-Kluczewska, Elżbieta (2012) „Can Tropes Be Seen?”. Journal of Kyiv National Linguistic University (KNLU). Series Philology 15 (2); 71-80.

Chrzanowska-Kluczewska, Elzbieta (2013) „Literary Semantics and Literary Pragmatics - (In Separable Disciplines?”. Biuletyn Polskiego Towarzystwa Językoznawczego LXIX; 77-94. Chrzanowska-Kluczewska, Elżbieta (2015) „Pomiędzy studiami nad tekstem literackim a semiotyką artystyczną". Stylistyka XXIV; 113-30. 
Deely, John (1988) „The Semiotics of John Poinsot: Yesterday and Tomorrow”. Semiotica 69; $31-127$.

Dressler, Wolfgang Ulrich (1995) „Interactions between Iconicity and Other Semiotic Parameters in Language". [W:] Simone, Raffaele (1995) (red.) Iconicity in Language. Amsterdam: John Benjamins; 21-37.

Dressler, Wolfgang Ulrich (1999) „On Semiotic Theory of Preferences in Language”. [W:] Michael Haley, Michael Shapiro (red.) The Peirce Seminar Papers. Essays in Semiotic Theory. Proceedings of the International Colloquium on Language and Peircean Sign Theory. New York: Bergham Books; 389-415.

Dressler, Wolfgang Ulrich (2003) „Naturalness and Morphological Change”. [W:] B. D. [brak wskazania imienia] Joseph, R.D.[brak wskazania imienia] Janda (red.) The Handbook of Historical Linguistics. Oxford: Blackwell; 461-471.

Dressler, Wolfgang Ulrich (2005) „Word-formation in Natural Morphology”. [W:] Pavol Štekauer, Rochelle Lieber (red.) Handbook of Word Formation. The Hague: Springer; 267 284.

Dressler, Wolfgang Ulrich, Lavinia Barbaresi (1994) Morphopragmatics. Diminiutives and Intensifiers in Italian, German and in Other Languages. Berlin: Mouton de Gruyter (Seria: Trends in Linguistics).

Dressler, Wolfgang Ulrich (2009) „Natural Phonology as Part of Natural Linguistics”. PSiCL $45(1) ; 33-42$.

Dziubalska-Kołaczyk, Katarzyna (2001-2002) „Challenges for Natural Linguistics in the Twenty-First Century”. University of Hawai'i Working Papers in Linguistics 23; 15-39.

Dziubalska-Kołaczyk, Katarzyna (2002) Beats-and-Binding Phonology. Frankfurt am Main (etc.): Peter Lang.

Gadnon, Francis (1997) „L'ambivalence théorique dans la recherche saussurienne sur la légende et les Notes item". Semiotica 115 (1/2); 173-189.

Goldmith, John, Laks Bernard (2016) „Battle in the Mind Fields: The First Four Generations”. [pobrane z: http://people.cs.uchicago.edu/ jagoldsm/battle/. Data ostatniego dostępu: 1412-2019].

Grzegorczykowa, Renata (1990) Wprowadzenie do semantyki językoznawczej. Warszawa: PIW. Haładewicz-Grzelak, Małgorzata (2012) „Dynamic Modeling of Visual Texts: a Relational Model”. Semiotica 190 (1/4); 211-251. 
Haładewicz-Grzelak, Małgorzata (2014) „Neogrammarian Ferdinand: a Natural hermeneutics of Mémoire sur le système primitif des voyelles dans les langues indo-européennes”. Acta Neophilologica XVI (1); 27-40.

Haładewicz-Grzelak, Małgorzata (2015) „Saussure's valeur sémiologique in the Case Study of Czech Sonants”. Semiotica 204; 361-390.

Haładewicz-Grzelak, Małgorzata (2017) „Coincidentia oppositorum in the oeuvre of André Martinet (1908-1999)”. Biuletyn Polskiego Towarzystwa Językoznawczego LXXIII; 2951.

Haładewicz-Grzelak, Małgorzata (2018) Semiotaktyczne studium sakrosfery na materiale wybranych wizualnych tekstów hierofanicznych. Opole: Oficyna Wydawnicza Politechniki Opolskiej.

Haładewicz-Grzelak, Małgorzata [w druku]. „Crowning, Rotating and Emanating Hierophanies with Elevatio Aspect in Wayside Shrines”. Przyjęte do druku w: Semiotica.

Hjemslev, Louis Trolle ([1963] 1970). Language: An Introduction. Milwaukee: University of Wisconsin Press.

Hjelmslev, Lous Trolle ([1943] 1953) Omkring sprogteoriens grundlaeggelse. Festskrift udgivet af Københavns Universitet $i$ anledning of Universitetets Aarsfest. København: Bianco Lunos bogtrykkeri a/s [Prolegomena to a Theory of Language] (thum.) Francis James Whitfield. Baltimore - Maryland - Baltimore: Waverly Press.

Jakobson, Roman (1973) Essais de Linguistique Générale. Paris: Les Éditions de Minuit.

Jakobson, Roman ([1976] 1978) Six Lectures on Sound and Meaning [Six leçons sur le son et le sens. Paris: Les Éditions de Minuit] (tłum.) John Mepham. Cambridge: CUP

Jakobson, Roman (1985) „My Favorite Topics”. [W:] Krystyna Pomorska, Stephen Rudy (red.) Verbal Art. Minneapolis: Minneapolis University Press; 3-10.

Jakobson, Roman ([1962]2002) Selected Writings. Berlin: Mouton de Gruyter.

Kim, Sung Do (1993) „La mythologie saussurienne: Une nouvelle vision sémiologique? (A propos de la continuité de la pensée saussurienne)". Semiotica 91 (1/2); 5-78.

Koerner, Ernst F. K. (1986) „Kruszewski’s Contribution to General Linguistic Theory”. [W:] Dieter Kastovsky, Aleksander Szwedek (red.) Linguistics Across Historical and Geographical Boundaries. In Honor of Jacek Fisiak on the Occasion of His $50^{\text {th }}$ Birthday. Berlin: Mouton de Gruyter; 53-76.

Koerner, Ernst F. K. (1995) „Mikołaj Kruszewski’s Contribution to General Linguistic Theory”. [W:] Ernst F. K. Koerner (red.) Writings in General Linguistics. On Sound Alteration 
(1881) and Outline of Linguistic Science (1883). Mikołaj Kruszewski (1851-1887). Amsterdam: John Benjamins Publishing Company; XI-XXXII.

Kristeva, Julia ([1981]1989) Language: the Unknown. An Introduction into Linguistics [La langue, cet inconnu. Paris: Éditions du Seuil]. (tłum.) Anne M. Menke. New York: Columbina University Press.

Kristeva, Julia (1969) „La sémiologie comme science des ideologies”. Semiotica 1 (2); 196204.

Kristeva, Julia ([1971] 1980) Desire in Language. A Semiotic Approach to Literature and Art. New York: Columbia University Press.

Kristeva, Julia (1974) La Revolution du Language Poétique. Paris: Éditions du SEUIL.

Kuryłowicz, Jerzy (1978) „Lecture du “Mémoire” en 1978: Un commentaire”. Cahiers Ferdinand de Saussure 32; 7-26.

„Le cercle de sémiotique de Paris” [brak wskazania autora]. Semiotica 4 (3); 286-294.

Lévi-Strauss, Claude (1978) „Preface”. [W:] Roman Jakobson ([1976] 1978) Six Lectures on Sound and Meaning. Cambridge: CUP; XI- XXVI.

Lévi-Strauss, Claude (1967) Structural Anthropology. New York: Anchor Books.

Martinet, André (1968) „Mot et syntheme”. Lingua 21; 294-302.

Marty, Robert (1990) L'Algèbre des signes. Essai de sémiotique scientifique d'après Charles Sanders Peirce (Series: Foundations of Semiotics. Vol. 24). Amsterdam: John Benjamins PC.

Morris, Charles (1964) Signification and Significance: A Study of the Relations of Signs and Values. Massachussets: The Massachusetts Institute of Technology Press.

Osgood, Charles, George Succi, Percy Tannenbaum ([1956] 1967) The Measurement of Meaning. Chicago: University of Illinois Press.

Percival, Keith (1981) „The Saussurean Paradigm: Fact or Fantasy?”. Semiotica 36; 33-49.

Percival, Keith (2011) „Roman Jakobson and the Birth of Linguistic Structuralism”. Sign Systems Studies 39; 236-262.

Pociechina, Helena (2009) Граммматическая вариантивность в славянских языках: Морфонологический аспект. Olsztyn: Wydawnictwo Uniwersytetu WarmińskoMazurskiego.

Puppel, Stanisław (2009) „An Ecological-ethnic Approach to Phonology: The Problem of Management of the Combined Resources of Space, Muscular Fitness, Resonance/Audition, and Time in Human Audio-Vocal Communication”. [W:] Marzena Wysocka (red.) On 
Language Structure, Acquisition and Teaching. Katowice: Wydawnictwo Uniwersytetu Śląskiego; 97-105.

Puppel, Stanisław (2017) ECOLI[S]2: Essays and Notes on Ecolinguistic Synergy and Synthesis. Poznań: Katedra Ekokomunikacji UAM/Zakład Graficzny UAM [pobrane z: http://keko.home.amu.edu.pl/sites/default/files/ECOLIS\%202_tekst_2017_0.pdf.. Data ostatniego dostępu: 14-12-2019].

Radwańska-Williams, Joanna (1993) A Paradigm Lost: The Linguistic Theory of Mikołaj Kruszewski. Amsterdam: John Benjamin’s Publishing Company.

Radwańska-Williams, Joanna (2006) „Examining our Patrimony: The Case of the Kazan School”. Historiographia Linguistica XXXIII (3); 357-390.

Saussure, Ferdinand de (1879) Mémoire sur le système primitif des voyelles dans les langues indo-européennes. Leipzig: Teubner.

Saussure, Ferdinand de ([2002] 2004) Szkice z językoznawstwa ogólnego. [Écrits de linguistique generale]. (tłum.) Magdalena Danielewiczowa. Warszawa: Dialog.

Saussure, Ferdinand de ([1916/1955]1991) Kurs językoznawstwa ogólnego [Cours de linguistique generale]. (tłum.) Krystyna Kasprzyk. Warszawa: Państwowe Wydawnictwo Naukowe.

Scheer, Tobias (2007) „(Direct) Interface Without Big Brothers”. (referat wygłoszony na międzynarodowej konferencji: The 2nd Student Conference on Formal Linguistics, 21-22 kwietnia 2007, Poznań).

Sebeok, Thomas A., Marcel Danesi (2000) The Forms of Meaning: Modelling Systems Theory and Semiotics. Berlin: Mouton de Gruyter.

Sebeok, Thomas A. (1994) An Introduction to Semiotics. Toronto: Toronto University Press.

Simone, Raffaele (1995) (red.) Iconicity in Language. Amsterdam: John Benjamins.

Stankiewicz, Edward (1983) „Roman Jakobson: A Commemorative Essay”. Semiotica 44 (1/2); $1-20$.

Stalmaszczyk, Piotr (red.) (2011) Metodologie językoznawstwa. Od genu języka do dyskursu. Łódź: Wydawnictwo UŁ.

Stalmaszczyk, Piotr (2008) „Semantyka formalna i pragmatyka”. Biuletyn Polskiego Towarzystwa Językoznawczego LXIV; 9-24.

Taverniers, Miriam (2008) „Hjelmslev’s Semiotic Model of Language: An Exegesis”. Semiotica $171(1 / 4) ; 367-394$.

Tobin, Yishai (red.) (1989) From Sign to Text in Linguistics, Literature and the Arts. Amsterdam: John Benjamins. 
Tobin, Yishai (1990) Semiotics and Linguistics. London: Longman.

Waugh, Linda, Monique Montiville-Bourston (2002) „Introduction to Roman Jakobson Selected Writings". [W:] Roman Jakobson ([1962] 2002) Selected Writings. Berlin: Mouton de Gruyter; V-XCVIII.

Wąsik, Zdzisław (1997) Systemowe i ekologiczne właściwości języka w interdyscyplinarnych podejściach badawczych. Wrocław: Wydawnictwo Uniwersytetu Wrocławskiego.

Wąsik, Zdzisław (1998) An Outline for Lectures in the Epistemology of Semiotics. Opole: Wydawnictwo Uniwersytetu Opolskiego.

Wąsik, Zdzisław (2014) Lectures on the Epistemology of Semiotics. Wrocław: Wydawnictwo Wyższej Szkoły Filologicznej we Wrocławiu.

Wąsik, Zdzisław (2017) From Grammar to Discourse: Towards a Solipsistic Paradigm of Semiotics. Poznań: Wydawnictwo UAM.

Wierzbicka, Anna (1999) Język-umyst-kultura. Warszawa: Państwowy Instytut Wydawniczy. Zinna, Alessandro (2017) „Hjelmslev, la sémiotique et l'École de Paris”. Semiotica 219; 455470.

\section{Źródla internetowe}

La langue française: https://www.lalanguefrancaise.com [data ostatniego dostępu 31-012021]. 